\title{
Metal Oxide Compact Electron Transport Layer Modification for Efficient and Stable Perovskite Solar Cells
}

\author{
Md. Shahiduzzaman ${ }^{1, *} \mathbb{1}$, Shoko Fukaya ${ }^{2}$, Ersan Y. Muslih ${ }^{3}$, Liangle Wang ${ }^{2}{ }^{\mathbb{D}}$, \\ Masahiro Nakano ${ }^{3}$, Md. Akhtaruzzaman ${ }^{4}$, Makoto Karakawa ${ }^{1,2,3}$, Kohshin Takahashi ${ }^{3}$, \\ Jean-Michel Nunzi ${ }^{1,5}$ (D) and Tetsuya Taima ${ }^{1,2,3, *}$ \\ 1 Nanomaterials Research Institute, Kanazawa University, Kakuma, Kanazawa 920-1192, Japan; \\ karakawa@staff.kanazawa-u.ac.jp (M.K.); nunzijm@queensu.ca (J.-M.N.) \\ 2 Graduate School of Frontier Science Initiative, Kanazawa University, Kakuma, Kanazawa 920-1192, Japan; \\ sheeepwing-tjkst@stu.kanazawa-u.ac.jp (S.F.); Bro.Wang@outlook.com (L.W.) \\ 3 Graduate School of Natural Science and Technology, Kanazawa University, Kakuma, Kanazawa 920-1192, \\ Japan; ersanmuslih@gmail.com (E.Y.M.); masahiro-nakano@se.kanazawa-u.ac.jp (M.N.); \\ ktakaha@se.kanazawa-u.ac.jp (K.T.) \\ 4 Solar Energy Research Institute, The National University of Malaysia, Bangi 43600, Malaysia; \\ akhtar@ukm.edu.my \\ 5 Department of Physics, Engineering Physics and Astronomy, Queens University, Kingston, \\ ON K7L-3N6, Canada \\ * Correspondence: shahiduzzaman@se.kanazawa-u.ac.jp (M.S.); taima@se.kanazawa-u.ac.jp (T.T.); \\ Tel.: +81-76-234-4937 (M.S.)
}

Received: 14 April 2020; Accepted: 9 May 2020; Published: 11 May 2020

\begin{abstract}
Perovskite solar cells (PSCs) have appeared as a promising design for next-generation thin-film photovoltaics because of their cost-efficient fabrication processes and excellent optoelectronic properties. However, PSCs containing a metal oxide compact layer (CL) suffer from poor long-term stability and performance. The quality of the underlying substrate strongly influences the growth of the perovskite layer. In turn, the perovskite film quality directly affects the efficiency and stability of the resultant PSCs. Thus, substrate modification with metal oxide CLs to produce highly efficient and stable PSCs has drawn attention. In this review, metal oxide-based electron transport layers (ETLs) used in PSCs and their systemic modification are reviewed. The roles of ETLs in the design and fabrication of efficient and stable PSCs are also discussed. This review will guide the further development of perovskite films with larger grains, higher crystallinity, and more homogeneous morphology, which correlate to higher stable PSC performance. The challenges and future research directions for PSCs containing compact ETLs are also described with the goal of improving their sustainability to reach new heights of clean energy production.
\end{abstract}

Keywords: metal oxide; compact layer; electron transport layer; modification layer; perovskite solar cells

\section{Introduction}

Energy is one of the fundamental necessities of our current society. At present, the ever-increasing world energy consumption relies on fossil energy resources. Burning fossil fuels releases greenhouse gases, causing global warming, which threatens the Earth's ecosystems. Therefore, it is strongly desired to explore alternative, carbon-free, renewable energy sources to replace fossil fuels. Solar energy is an attractive alternative energy source because it is the largest usable source that could potentially meet global future energy demands. A solar cell is a device that converts solar energy directly into electrical 
energy. Solar cells make no noise or pollution and have no moving parts, making them robust, reliable, and long-lasting [1-3]. The development of alternative power systems that harvest ambient energy sources (radiant, thermal, and mechanical energy) is desired in order to perpetually power or recharge Internet of Things devices. Solar cells possess several advantageous features, including high stability and a cost-effective fabrication process. Because of these features, solar cells are expected to act as long-term power supplies for satellites and space vehicles [4].

The majority of research on solar cells has focused on silicon-based assemblies, in which silicon is used as both the light absorber and charge transporter [5]. However, the high processing cost, toxicity of silicon-based chemicals, and high energy demands for cell fabrication are disadvantages that currently limit the wide application of silicon-based solar cells. The buildings where such solar cells can be installed are limited. Researchers have been exploring potential next-generation solar cell technologies that are cheap and can be processed using simple solution-based techniques. Solution-based processing has been used to fabricate various types of photovoltaic cells, such as organic photovoltaics, dye-sensitized solar cells, quantum dot solar cells, and perovskite solar cells (PSCs), making these cells attractive lost-cost alternatives to silicon solar cells.

Perovskites are minerals with the same structure as calcium titanium oxide $\left(\mathrm{CaTiO}_{3}\right)$ and are named after the Russian Geographical Society founder Lev Perovski. The light harvester in PSCs is a perovskite such as methylammonium lead iodide $\left(\mathrm{CH}_{3} \mathrm{NH}_{3} \mathrm{PbI}_{3}\right)$, with a general formula $\mathrm{ABX}$, where " $\mathrm{A}$ " is a univalent organic cation $\left(\mathrm{CH}_{3} \mathrm{NH}_{3}{ }^{+}\right)$, " $\mathrm{B}$ " is a bivalent metal ion $\left(\mathrm{Pb}^{2+}\right)$ and " $\mathrm{X}$ " is a halide $\left(\mathrm{I}^{-}\right)$ anion (Figure 1a). Here, A coordinates with $12 \mathrm{X}$ anions and $\mathrm{B}$ coordinates with six $\mathrm{X}$ anions, forming a geometry of cubes and octahedrons, respectively. The crystal structure and perovskite arrangement can be estimated using the Goldschmidt tolerance factor. Hybrid organic-inorganic metal halide PSCs are currently the fastest growing technology in the history of photovoltaics. Such PSCs have attracted broad interest from academic and industrial communities because of their favorable optoelectronic properties, such as tunable bandgap, high absorption coefficient, high electron and hole mobilities, long diffusion lengths $(>1 \mu \mathrm{m})$, and easy and inexpensive fabrication by solution processing [6-9]. Intensive research efforts around the world have led to great improvements in the power conversion efficiency (PCE) of PSCs since their original PCE of 3.8\% was reported by Miyasaka and co-workers in 2009 [10]. In just over a decade, the PCE of PSCs has rapidly increased to reach the latest record of $25.2 \%$, approaching the top values achieved for single-crystalline silicon solar cells [11]. There are two leading types of device architecture that yield efficient PSCs: planar heterojunctions (PHJs) and mesoporous $(\mathrm{mp})$ structures. Because of their facile device processing and efficient performance, PHJ PSCs have attracted more research interest than mp-PSCs. Typical PSCs have a sandwich structure consisting of a perovskite photoactive layer with a thickness of several hundred nanometers between metal oxide $\left(\mathrm{MO}_{\mathrm{x}}\right)$ layers; namely, an electron transport layer (ETL) and hole-transport layer (HTL) (Figure 1b). When a perovskite device is illuminated by a standard simulated solar spectrum, charge carriers are generated within the perovskite photosensitive layer, separated by the ETL and HTL, and collected at their respective electrodes, thereby generating an electric current. A schematic illustration of the energy-level alignment between device components is shown in Figure 1c. The ETL needs to transport photogenerated electrons and block holes to eradicate the electrical shunt and afford stable PSCs with high performance. Figure 1d shows the progress in PSC efficiency by year.

With the rapid improvement of PSC performance, device lifetime (operational stability) has become the main concern for their future commercialization. PSC stability can be affected by both extrinsic (environmental) and intrinsic factors. Environmental factors include moisture, oxygen, light, and heat, which can degrade the photoactivity of the perovskite components [12]. The intrinsic stability of perovskites is strongly influenced by the presence of defects in the perovskite layer and at the interface between the perovskite and charge transport layers [13]. Perovskite instability is dominated by the hygroscopic nature of the organic cations, under-coordinated lead atoms, thermal instability, and ion migration. The PSC degradation driven by the hygroscopic character of the organic cations is correlated with environmental factors, which can be resolved by device encapsulation [14]. Thermal 
instability can be addressed by compositional engineering of the perovskite and inorganic materials used in the HTL [15-17]. Recently, Miyasaka et al. reported the design and fabrication of high-quality perovskite films and dopant-free HTLs for efficient and stable PSCs [18]. Ion migration in perovskite films is another origin of PSC degradation. Ion migration initiated by the illumination-induced electric field can be hindered or even stopped by passivating the grain boundaries in the device; that is, through interfacial modification [19]. Furthermore, ion substitution can decrease the packing density of the crystal lattice [20]. Interfacial modification can also lower the density of recombination hubs correlated with under-coordinated lead atoms or organohalide defect sites, consequently improving the overall PSC performance [21]. Modification of the ETL/perovskite interface plays roles in facilitating charge transport and suppressing hysteresis and interfacial recombination to realize highly efficient and stable PSCs [22]. Therefore, it is immensely desirable to develop facile techniques for the modification of ETL/perovskite interfaces to enable efficient fabrication of low-cost and highly stable PSCs. The present mini-review summarizes recent progress on $\mathrm{MO}_{\mathrm{x}}$ compact ETLs and their systemic modification to realize high-efficiency and stable PSCs.
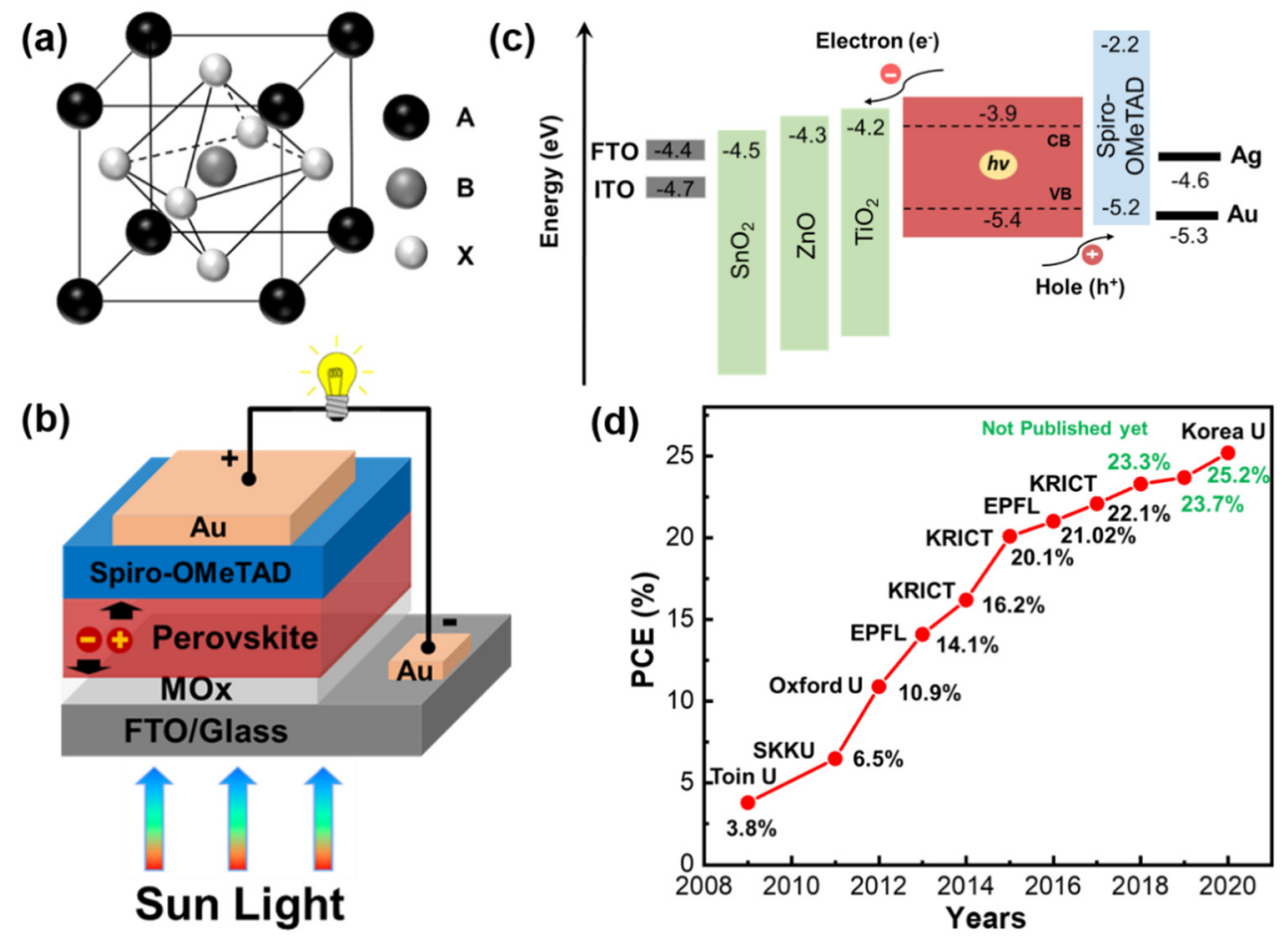

Figure 1. (a) General structure of a perovskite, (b) schematic of a perovskite solar cell with various layers, (c) energy band alignment of $\mathrm{MAPbI}_{3}$ perovskite and various metal oxide electron transport materials in the device, and (d) performances evolution of perovskite solar cells certified by National Renewable Energy Laboratory (NREL) (14.1\% [23], 16.2\% [24], 20.1\% [25], 21.02\% [26] and 22.1\% [27]). The green power conversion efficiencies (PCEs, 23.3\%, 23.7\%, and 25.2\%) are not in the public domain yet. SKKU, EPFL, and KRICT denote Sungkyunkwan University, École polytechnique fédérale de Lausanne, and Korea Research Institute of Chemical Technology, respectively.

\section{Metal Oxide Compact Electron Transport Layers}

$\mathrm{MO}_{\mathrm{x}}$ is the most uplifting design with respect to the thin-film processing, electronic structure, charge transport mechanisms, defect states, and optoelectronic properties [28]. However, $\mathrm{MO}_{\mathrm{x}}$ are promising materials in PSCs because they suppress the electrical shunt between the transparent electrode/perovskite and transparent electrode/HTL interfaces as well as permitting electron transport and blocking hole transport to the respective electrode $[29,30] . \mathrm{MO}_{\mathrm{x}}$ compact electron transport materials such as titanium dioxide $\left(\mathrm{TiO}_{2}\right)$ [31], zinc oxide $(\mathrm{ZnO})$ [32], tin oxide $\left(\mathrm{SnO}_{2}\right)$ [33], zinc stannate 
$\left(\mathrm{Zn}_{2} \mathrm{SnO}_{4}\right)$ [34], zirconium dioxide $\left(\mathrm{ZrO}_{2}\right)$ [35], tungsten oxide $\left(\mathrm{WO}_{3}\right)$ [36], and niobium pentoxide $\left(\mathrm{Nb}_{2} \mathrm{O}_{5}\right)$ [37], can be used as compact ETLs. In particular, efficient PSCs have been fabricated using $\mathrm{TiO}_{2}, \mathrm{SnO}_{2}$ and $\mathrm{ZnO}$ films as ETLs.

\section{Titanium Dioxide $\left(\mathrm{TiO}_{2}\right)$}

The anatase (tetragonal), brookite (orthorhombic), and rutile (tetragonal) polymorphs of $\mathrm{TiO}_{2}$ possess distinct crystalline phases and unique properties and have been widely used as photocatalysts [38] and in solar cells [39]. $\mathrm{TiO}_{2}$ is the most promising material used in n-type ETLs for efficient PSCs because of its environmentally friendly nature, tunable electronic properties, low cost, and conduction band that is well matched with that of perovskites, thus facilitating electron injection and collection. However, the use of $\mathrm{TiO}_{2}$ film in PHJ PSCs has the following drawbacks. (i) The low conductivity and electron mobility of $\mathrm{TiO}_{2}$ are unfavorable for electron collection and transport [40,41]. (ii) Exposure of $\mathrm{TiO}_{2}$ to ultraviolet light induces the formation of oxygen vacancies at the surface and grain boundaries of $\mathrm{TiO}_{2}$ that act as charge traps and result in severe loss of photogenerated carriers through recombination [42,43]. Thus, the interface between $\mathrm{TiO}_{2}$ and perovskite retards the photoresponse of the resultant devices and leads to strong hysteresis [41]. Considerable effort has been devoted to improving the performance of PSCs by resolving these drawbacks by modification of $\mathrm{TiO}_{2}$ compact layers (CLs) via interface engineering and elemental doping. The surface morphology and properties of the $\mathrm{TiO}_{2} \mathrm{CL}$ of PSCs strongly affect the quality of the perovskite photosensitive layer in terms of the crystal size, homogeneity, and surface coverage, which in turn influence the photovoltaic performance [44]. The systemic modification of $\mathrm{TiO}_{2}$ ETLs is important to optimize the efficiency and stability of PSCs.

\section{1. $\mathrm{TiO}_{2}$ Compact Layers (CLs)}

PHJ PSCs with $\mathrm{TiO}_{2}$ ETLs have received more research interest than mp-architectures because of their potential to realize low-temperature processing, simple device framework, and high-throughput roll-to-roll manufacturing. Optimization of deposition methods of $\mathrm{TiO}_{2} \mathrm{CLs}$ is important to achieve uniform compact thickness to maximize the charge transport capacity between the $\mathrm{TiO}_{2} \mathrm{CL}$ and perovskite. In addition, the thickness of the $\mathrm{TiO}_{2} \mathrm{CL}$ needs to be optimized to maximize electron transport from the perovskite to the fluoride-doped tin oxide (FTO) electrode. When the $\mathrm{TiO}_{2} \mathrm{CL}$ is too thick, the resultant increase of the distance of electron transport from the perovskite to FTO lowers the efficiency of charge transport [45]. Conversely, a $\mathrm{TiO}_{2} \mathrm{CL}$ that is too thin cannot efficiently cover the FTO substrate. Numerous deposition techniques have been used to form $\mathrm{TiO}_{2}$ CLs in PSCs, such as the sol-gel method [46], oblique electrostatic inkjet (OEI) deposition, chemical bath deposition (CBD) [47,48], spray pyrolysis [49], atomic layer deposition (ALD) [50], thermal oxidation [31], sputtering [51], chemical vapor deposition (CVD) [52], and electrodeposition [53]. Spin coating is a commonly used simple and robust technique to form $\mathrm{TiO}_{2} \mathrm{CLs}$. However, this approach cannot produce high-quality $\mathrm{TiO}_{2}$ CLs and has limited suitability for large-scale production. Spray pyrolysis sprays a titanium precursor onto a heated substrate using an atomizer. The precursor droplets thermally decompose to form a $\mathrm{TiO}_{2} \mathrm{CL}$. The $\mathrm{TiO}_{2} \mathrm{CLs}$ produced through either spin coating or spray deposition are particularly sensitive to control parameters. Consequently, the PCE of PSCs may differ considerably even when using the same technique to form $\mathrm{TiO}_{2}$ CLs. ALD is a scalable technique for the preparation of $\mathrm{TiO}_{2} \mathrm{CLs}$, but is relatively time consuming and expensive. $\mathrm{CVD}$ and sputtering require vacuum conditions and have slow deposition rates, which make them expensive and inconvenient for the production of $\mathrm{TiO}_{2} \mathrm{CLs}$. Below, we discuss a few commonly used simple and efficient approaches to pattern $\mathrm{TiO}_{2}$ CLs for PSCs.

\subsubsection{Sol-Gel Technique}

The sol-gel approach is widely considered to be a promising technique for the deposition of $\mathrm{TiO}_{2}$ CLs because of its simplicity. Segawa and co-workers demonstrated the surface treatment of 
$\mathrm{TiO}_{2}$ CLs using an aqueous solution of $\mathrm{TiCl}_{4}$ and ultraviolet/ozone to enhance the wettability and interface adhesion between the $\mathrm{TiO}_{2} \mathrm{CL}$ and perovskite [54]. The resultant PHJ PSCs showed PCEs of up to $16.9 \%$. Zhou et al. reported planar PSCs with a PCE of $19.3 \%$ based on indium tin oxide (ITO)-coated glass treated with ethoxylated polyethyleneimine and a low-temperature $\mathrm{TiO}_{2}$ CL [55]. In addition, to increase the conductivity of the $\mathrm{TiO}_{2} \mathrm{CL}$, it was doped with yttrium. The favorable band alignment of yttrium-doped $\mathrm{TiO}_{2}$ with the perovskite and ITO facilitated efficient electron injection and collection and suppressed interfacial recombination. Choi et al. reported PHJ PSCs with a PCE of $16.3 \%$ containing $\mathrm{TiO}_{x}$ CLs formed by a simple sol-gel process at room temperature [56]. The performance of these PSCs was comparable to that of cells containing $\mathrm{TiO}_{2}$ CLs fabricated at high temperature. Additionally, the room temperature-processed $\mathrm{TiO}_{\mathrm{x}} \mathrm{CL}$ was used as an ETL in a flexible PSC that achieved a PCE of $14.3 \%$. Liu et al. treated low-temperature-processed $\mathrm{TiO}_{2} \mathrm{CLs}$ with various concentrations of aqueous $\mathrm{TiCl}_{4}$ solutions to form ETLs that were uniform, pinhole-free, and had full surface coverage [57]. PSCs containing these ETLs showed efficient electron transport, charge extraction, and suppressed charge recombination, which led to enhanced photovoltaic performance.

\subsubsection{Chemical Bath Deposition (CBD)}

$\mathrm{CBD}$ is a simple, inexpensive, convenient, and scalable technique to pattern $\mathrm{TiO}_{\mathrm{x}} \mathrm{CLs}$ from aqueous solutions, making it advantageous for large-scale production of thin films for organic photovoltaic cells and PSCs [58]. Several reports have been published about CBD $\mathrm{TiO}_{2}$-based PSCs. Recently, Liu and co-workers reported PSCs containing co-doped $\mathrm{TiO}_{2}$ ETLs formed by low-temperature CBD with a PCE of $19.10 \%$ [59]. In addition, the group led by Takahashi and Kuwabara developed a technique to pattern $\mathrm{TiO}_{\mathrm{x}}$ films at low temperatures and used them as ETLs in organic photovoltaic cells that exhibited a PCE of 3.8\% under AM1.5G simulated sunlight [60]. $\mathrm{TiO}_{2}$ CLs fabricated by $\mathrm{CBD}$ form good physical and electronic contacts with perovskite photosensitive layers. We reported PHJ PSCs with $\mathrm{TiO}_{x}$ CLs formed by CBD and modified with a thin layer of fullerene or a derivative as ETLs $[47,48,61,62]$. The scalable CBD technique solely enables production of $\mathrm{TiO}_{\mathrm{x}}$ CLs at low temperature [63]. Photographs of the hydrolysis steps of CBD are shown in Figure 2. A $30 \mathrm{~nm} \mathrm{TiO}_{\mathrm{x}}$ film is formed in a single operation. The thickness of $\mathrm{TiO}_{\mathrm{x}}$ can be increased by repeating the operation. However, it is quite difficult to control the morphology and thickness of $\mathrm{TiO}_{2}$ CLs fabricated by CBD, which leads to poor reproducibility. Therefore, it remains important to develop a technique to fabricate high-quality $\mathrm{TiO}_{2}$ CLs for efficient PHJ PSCs that is scalable, controllable, and low cost. This process can be used for roll-to-roll production, which may contribute it a potential candidate for low-cost commercial production of $\mathrm{TiO}_{2}$-based ETLs in future solar modules.

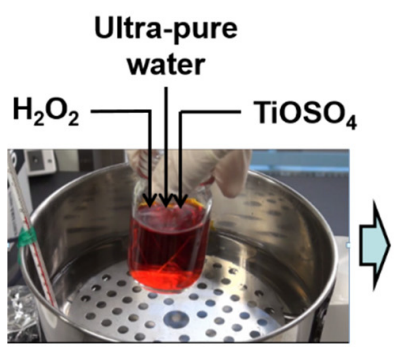

Mix-Precursor solution

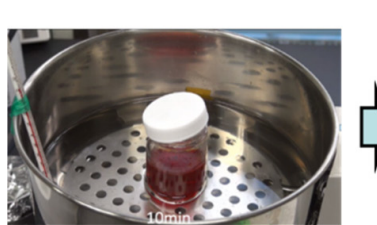

Deposition starting (0 sec)

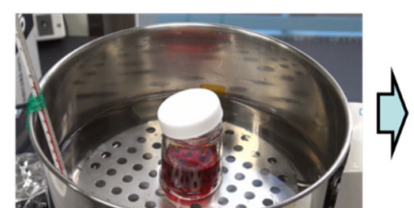

Immersed in oil bath at $80^{\circ} \mathrm{C}$

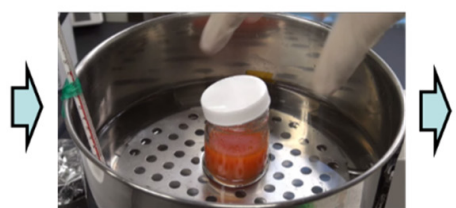

$30 \mathrm{sec}$ after deposition

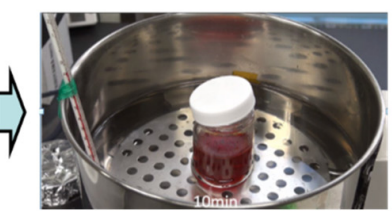

Clouding point (10 $\mathrm{min})$

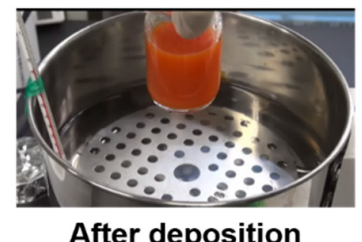

(6 min)

Figure 2. Photographs illustrating the hydrolysis steps in chemical bath deposition of $\mathrm{TiO}_{\mathrm{x}}$ films. 


\subsubsection{Inkjet Printing Approaches}

Inkjet printing is a scalable technique that is compatible with roll-to-roll processing. In addition, inkjet printing is cost-effective and has a high material utilization rate, which may lower the production cost of devices. Wei et al. reported efficient PSCs containing $\mathrm{TiO}_{2} \mathrm{CLs}$ formed by electrodeposition [53]. Electrodeposition is a simple, cost-effective, and scalable technique to pattern uniform $\mathrm{TiO}_{2}$ CLs. The surface morphology and thickness of $\mathrm{TiO}_{2}$ CLs can be controlled by simply manipulating deposition conditions. In addition, we recently developed an OEI bottom-up strategy to produce $\mathrm{TiO}_{2}$ CLs that involves discharging a spray using electrostatic force. In the OEI strategy, an FTO substrate was patterned with a $\mathrm{TiO}_{2}$ precursor solution using an ejection angle of $45^{\circ}$ with respect to the substrate (Figure 3a). The OEI technique produced high-quality $\mathrm{TiO}_{2} \mathrm{CLs}$ on FTO substrates, which were used as the ETL in PSCs that showed a PCE of 13.19\% [64]. Unlike other bottom-up techniques, OEI deposition offers a simple and cost-effective way to obtain high-quality $\mathrm{TiO}_{2}$ films with easy-to-control thickness. Using OEI deposition, large-area stacked thin films can be fabricated with high reproducibility. The surface morphology of $\mathrm{TiO}_{2}$ films was tuned by simply changing the coating time. Large-scale printing using OEI deposition may be realized by changing the single nozzle system to one with multiple nozzles. OEI deposition can be used to pattern a variety of substrates on a large scale to achieve high-throughput, large-area perovskite solar modules. The scalability, large-area uniformity, and low-cost fabrication capability with a high material utilization rate of OEI deposition might lower the production cost of resultant devices. This simple technique to fabricate $\mathrm{TiO}_{2} \mathrm{CLs}$ may help to further improve the photovoltaic performance of planar small- and large-scale PSC modules.
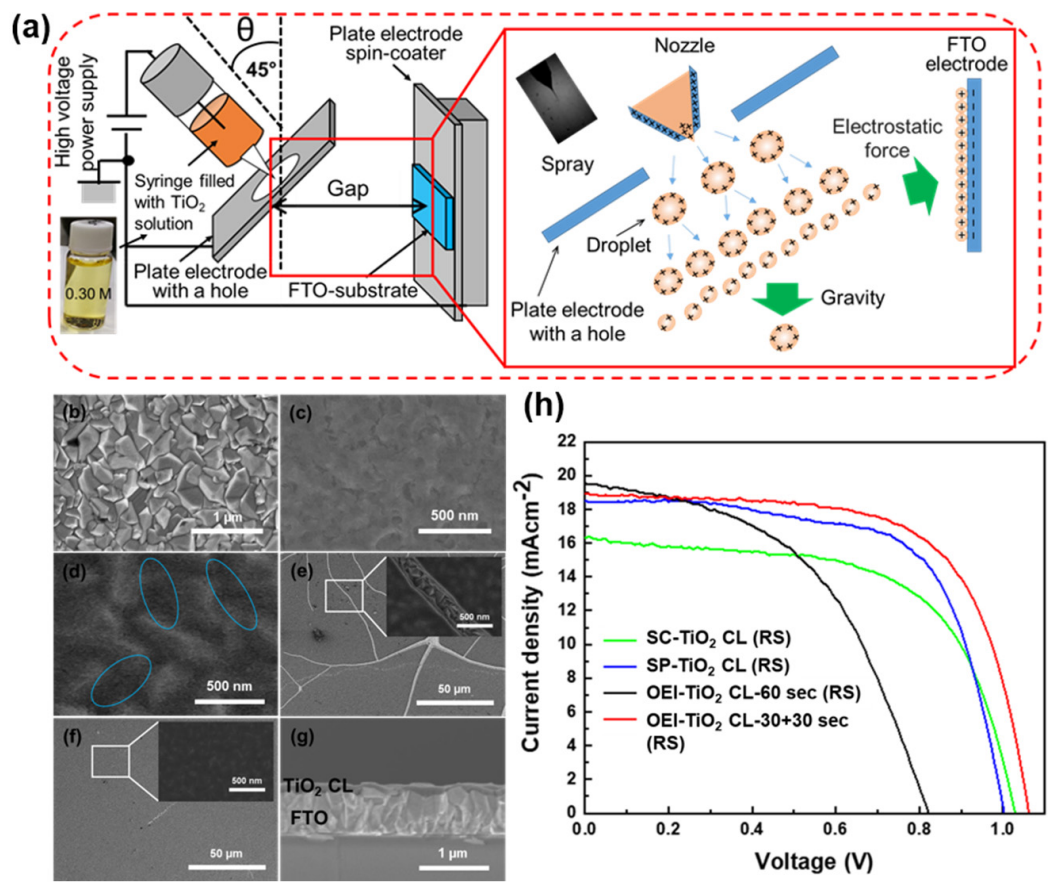

Figure 3. (a) Schematic of the oblique electrostatic inkjet (OEI) setup used to pattern $\mathrm{TiO}_{2}$ compact layers (CLs) on fluoride-doped tin oxide (FTO)-coated glass substrates. Top-view scanning electron microscope (SEM) images of (b) bare FTO, (c) spin coating (SC)- $\mathrm{TiO}_{2} \mathrm{CL}$, (d) spray pyrolysis (SP)-TiO 2 $\mathrm{CL}$, (e) OEI-TiO 2 CL-60 s, and (f) $\mathrm{OEI}-T i O_{2}$ CL-30 + 30 s. (g) Cross-sectional SEM image of the $\mathrm{OEI}^{-\mathrm{TiO}_{2}}$ CL-30 + 30 s film. (h) Reverse $J-V$ characteristics of perovskite solar cells (PSCs) made under different conditions. Reproduced with permission [64]. Copyright 2019, Springer Nature.

\subsection{Surface Modification by $\mathrm{TiO}_{2}$ Nanoparticles}

To improve the performance and stability of PSCs, there has been significant focus upon the surface modification of ETLs. $\mathrm{TiO}_{2}$ nanoparticles (NPs) possess a higher specific surface area than that 
of $\mathrm{TiO}_{2} \mathrm{CLs}$, enabling the surface morphology of $\mathrm{TiO}_{2}$ films to be tuned. $\mathrm{TiO}_{2} \mathrm{NPs}$ can promote efficient electron injection and transport to improve the balance of charge carriers. The anatase phase of $\mathrm{TiO}_{2}$ is extensively used as the ETL in PSCs because of its easy synthesis. Conversely, the brookite phase of $\mathrm{TiO}_{2}$ is the least explored because it is difficult to synthesize the pure brookite phase. The rutile phase of $\mathrm{TiO}_{2}$ also shows potential for use as an ETL in PSC applications. $\mathrm{TiO}_{2}$ CLs composed of mixtures of anatase and rutile phases have been used in PSCs. To explore the performance of different polymorphs of $\mathrm{TiO}_{2}$-based PSCs, it is important to understand the effect of $\mathrm{TiO}_{2}$ microstructure on PSC performance and stability. At present, inorganic metal oxides $\left(\mathrm{TiO}_{2} \mathrm{NPs}, \mathrm{mp}-\mathrm{TiO}_{2}\right)$ and organics such as self-assembling monolayers (SAM), fullerene $\left(\mathrm{C}_{60}\right),[6,6]-$ phenyl- $\mathrm{C}_{61}$-butyric acid methyl ester (PCBM) based materials are used to combine with or modify $\mathrm{TiO}_{2} \mathrm{CL}, \mathrm{SnO}_{2}, \mathrm{ZnO}$ in PSCs and their corresponding device architectures and PCEs are included in Table 1.

Table 1. Examples of surface modification of $\mathrm{TiO}_{2}, \mathrm{SnO}_{2}$ and $\mathrm{ZnO} \mathrm{CL}$ in PSCs. The corresponding device architectures and PCEs are derived.

\begin{tabular}{|c|c|c|c|}
\hline Surface Modification & Devices Structure & PCE (\%) & Ref. \\
\hline $\mathrm{TiO}_{2}$ /anatase $\mathrm{TiO}_{2} \mathrm{NPs}$ & $\mathrm{FTO} / \mathrm{TiO}_{2} /$ anatase $\mathrm{TiO}_{2} \mathrm{NPs} / \mathrm{MAPbI}_{3} / \mathrm{Spiro} / \mathrm{Au}$ & 17.1 & [65] \\
\hline $\mathrm{TiO}_{2} /$ brookite $\mathrm{TiO}_{2} \mathrm{NPs}$ & $\begin{array}{c}\mathrm{FTO} / \mathrm{TiO}_{2} / \text { brookite } \\
\mathrm{TiO}_{2} \mathrm{NPs} / \mathrm{Cs}_{0.05}\left(\mathrm{FA}_{0.83} \mathrm{MA}_{0.17}\right)_{0.95} \mathrm{~Pb}_{\left(\mathrm{I}_{03}{ }_{3} \mathrm{Br}_{017}\right)_{3} / \text { Spiro/Au } \mathrm{Au}}\end{array}$ & 16.8 & [66] \\
\hline $\mathrm{TiO}_{2} /$ brookite $\mathrm{TiO}_{2}$ NPs & $\mathrm{FTO} / \mathrm{TiO}_{2} /$ brookite $\mathrm{TiO}_{2} \mathrm{NPs} / \mathrm{MAPbI}_{3} / \mathrm{Spiro} / \mathrm{Au}$ & 18.2 & [67] \\
\hline $\mathrm{TiO}_{2} / \mathrm{mp}-\mathrm{TiO}_{2}$ & $\mathrm{FTO} / \mathrm{TiO}_{2} / \mathrm{mp}-\mathrm{TiO}_{2} / \mathrm{Cs}_{0.05}\left(\mathrm{FA}_{0.83} \mathrm{MA}_{0.17}\right)_{0.95} \mathrm{~Pb}\left(\mathrm{I}_{0.83} \mathrm{Br}_{0.17}\right)_{3} / \mathrm{Spiro} / \mathrm{Au}$ & 21.1 & [44] \\
\hline $\mathrm{TiO}_{2} /$ rutile $\mathrm{TiO}_{2} \mathrm{NRs}$ & $\mathrm{FTO} / \mathrm{TiO}_{2} /$ rutile $\mathrm{TiO}_{2} \mathrm{NPs} / \mathrm{MAPbI}_{3} / \mathrm{Spiro} / \mathrm{Ag}$ & 18.2 & [68] \\
\hline $\mathrm{TiO}_{2} / \mathrm{C} 60$ & $\mathrm{ITO} / \mathrm{TiO}_{2} / \mathrm{C} 60 / \mathrm{MAPbI}_{3} / \mathrm{Spiro} / \mathrm{Ag}$ & 9.5 & [47] \\
\hline $\mathrm{TiO}_{2} / \mathrm{PDI}$-glass & $\mathrm{ITO} / \mathrm{TiO}_{2} / \mathrm{PDI}$-glass/MAPbI $/$ /Spiro/Au & 5.7 & [61] \\
\hline $\mathrm{TiO}_{2} / \mathrm{PNP}$ & $\mathrm{ITO} / \mathrm{TiO}_{2} / \mathrm{PNP} / \mathrm{MAPbI}_{3} /$ Spiro/Ag & 8.2 & [48] \\
\hline $\mathrm{TiO}_{2} / \mathrm{SnO}_{2}$ & $\mathrm{FTO} / \mathrm{TiO}_{2} / \mathrm{SnO}_{2} / \mathrm{MAPbI}_{3} / \mathrm{PATT} / \mathrm{Au}$ & 19.8 & [69] \\
\hline $\mathrm{TiO}_{2} / \mathrm{SnO}_{2}$ & $\mathrm{FTO} / \mathrm{TiO}_{2} / \mathrm{SnO}_{2} / \mathrm{FA}_{0.83} \mathrm{MA}_{0.17}\left(\mathrm{Ge}_{0.03} \mathrm{~Pb}_{0.97}\left(\mathrm{I}_{0.9} \mathrm{Br}_{0.1}\right)_{3} /\right.$ Spiro/Au & 22.1 & [70] \\
\hline $\mathrm{TiO}_{2} / \mathrm{SnO}_{2}$ & $\mathrm{FTO} / \mathrm{TiO}_{2} / \mathrm{SnO}_{2} / \mathrm{MAPbI}_{3} / \mathrm{Spiro} / \mathrm{Ag}$ & 21.1 & [71] \\
\hline $\mathrm{TiO}_{2} / \mathrm{SnO}_{2}$ & $\mathrm{ITO} / \mathrm{TiO}_{2} / \mathrm{SnO}_{2} / \mathrm{FA}_{0.95} \mathrm{Cs}_{0.05} \mathrm{PbI}_{3} / \mathrm{PCBM} / \mathrm{Ag}$ & 21.5 & [72] \\
\hline $\mathrm{SnO}_{2} / \mathrm{SAM}$ & $\mathrm{FTO} / \mathrm{SnO}_{2} / \mathrm{SAM} / \mathrm{MAPbI}_{3} / \mathrm{Spiro} / \mathrm{Au}$ & 18.8 & [73] \\
\hline $\mathrm{SnO}_{2} / \mathrm{PCBM}$ & $\mathrm{FTO} / \mathrm{SnO}_{2} / \mathrm{PCBM} / \mathrm{MAPbI}_{3} / \mathrm{Spiro} / \mathrm{Au}$ & 19.1 & [74] \\
\hline $\mathrm{ZnO} / \mathrm{SnO}_{2}$ & $\mathrm{FTO} / \mathrm{SnO}_{2} / \mathrm{PCBM} / \mathrm{MAPbI}_{3} / \mathrm{Spiro} / \mathrm{Ag}$ & 12.17 & [75] \\
\hline $\mathrm{ZnO} / \mathrm{SAM}$ & $\mathrm{ITO} / \mathrm{ZnO} / \mathrm{SAM} / \mathrm{MAPbI}_{3} /$ Spiro & 13.7 & [32] \\
\hline
\end{tabular}

\subsubsection{Anatase $\mathrm{TiO}_{2}$ Nanoparticles (NPs)}

We found that introduction of single-crystalline anatase $\mathrm{TiO}_{2} \mathrm{NPs}$, which were synthesized by a hydrothermal approach [76], between the $\mathrm{TiO}_{2} \mathrm{CL}$ and perovskite layer altered the interface surface morphology to provide highly efficient and stable PSCs [65]. $\mathrm{TiO}_{2} \mathrm{NPs}$ are water soluble and have a low content of carbon per titanium atom, which make them attractive reagents to prepare titanium-containing functional materials. Large grains with fewer grain boundaries were observed in the perovskite layer when $\mathrm{TiO}_{2} \mathrm{NPs}$ were introduced between the $\mathrm{TiO}_{2} \mathrm{CL}$ and perovskite, which facilitated efficient electron extraction and suppressed charge carrier recombination. PSCs containing the $\mathrm{TiO}_{2} \mathrm{CL} /$ anatase $\mathrm{TiO}_{2} \mathrm{NP}$ bilayer showed a PCE of $17.05 \%$ and decreased hysteresis (Figure 4) compared with that of the equivalent device without $\mathrm{TiO}_{2} \mathrm{NPs}$. We also investigated the moisture stability of these bilayer-based PSCs stored a dry, dark $\mathrm{N}_{2}$ environment. The PCE of the bilayer-based device showed remarkable long-term moisture stability, deteriorating to $38 \%$ of its initial PCE after 47 days. Gan et al. fabricated PSCs with a PCE of up to $3.7 \%$ by using $\mathrm{TiO}_{2}$ nanorods with a length of $600 \mathrm{~nm}$ as an ETL scaffold [77]. He and his colleagues reported efficient PSCs containing an ETL of single-crystalline $\mathrm{TiO}_{2}$ nanorods with an average length of $30 \pm 10 \mathrm{~nm}$ and diameter of $4 \pm 1 \mathrm{~nm}$ that exhibited a PCE of over 17\% [78]. The one-dimensional nanostructure acted solely as a CL in the high-performance PSCs. In other work, high-performance stable PSCs were produced by adding $\mathrm{TiO}_{2}$ NPs to a perovskite precursor solution to tune the perovskite morphology [79]. The tuned perovskite morphology improved electron extraction, thereby enhancing the PCE of the PSCs to $19.2 \%$. 

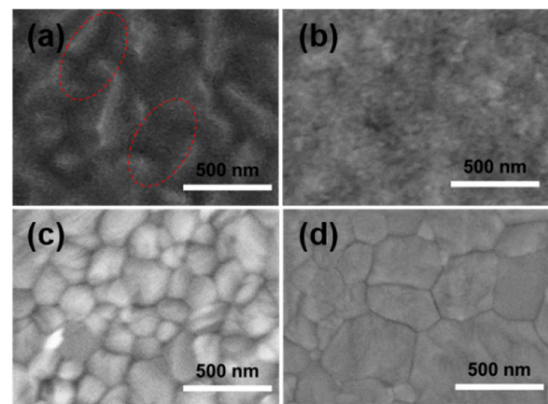

(d)

(f)

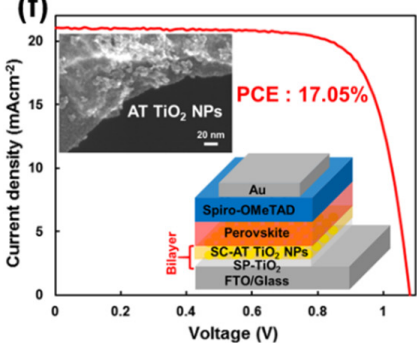

(e) $\mathrm{Pbl}_{2}+\mathrm{CH}_{3} \mathrm{NH}_{3} \mathrm{I} / \mathrm{DMF}+\mathrm{DMSO}$

(I) Solvent

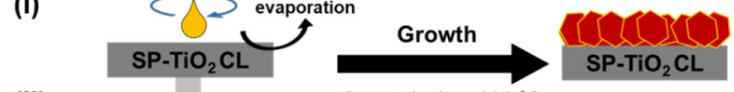

(II)

Annealed at $100^{\circ} \mathrm{C}$ $\mathrm{Pbl}_{2}+\mathrm{CH}_{3} \mathrm{NH}_{3} \mathrm{l} / \mathrm{DMF}+\mathrm{DMSO}$

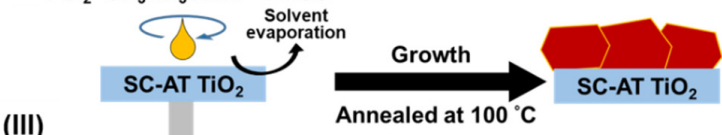

(III)

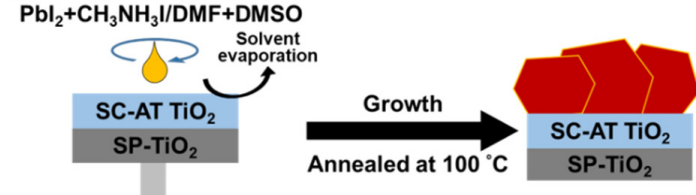

Primary nucleation dominates by a single-crystalline compact AT TiO ${ }_{2} \mathrm{NPs}$

- AT $\mathrm{TiO}_{2}$ nanoparticles (NPs) $\longrightarrow \mathrm{CH}_{3} \mathrm{NH}_{3} \mathrm{Pbl}_{3}$ grain

Figure 4. $\mathrm{SEM}$ images of the (a) $\mathrm{SP}-\mathrm{TiO}_{2}$ layer and (b) $\mathrm{SP}-\mathrm{TiO}_{2} / \mathrm{SC}$-anatase (AT) $\mathrm{TiO}_{2}$ nanoparticle (NP) bilayer and perovskite films grown on the (c) $\mathrm{SP}-\mathrm{TiO}_{2}$ layer and (d) $\mathrm{SP}-\mathrm{TiO}_{2} / \mathrm{SC}-\mathrm{AT} \mathrm{TiO}_{2} \mathrm{NP}$ bilayer. (e) Schematic of the nucleation and growth of perovskite grains. (f) Reverse $J-V$ curve obtained for a solar cell with the NP bilayer. Insets shows the device structure and an SEM image of the NPs. Reproduced with permission [65]. Copyright 2018 American Chemical Society.

\subsubsection{Brookite $\mathrm{TiO}_{2} \mathrm{NPs}$}

Among the three polymorphs of $\mathrm{TiO}_{2}$, the brookite phase has been used the least in PSCs because

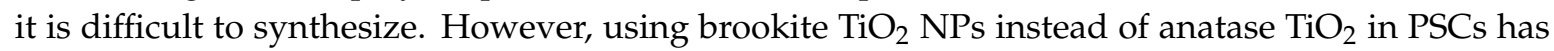
numerous advantages. Compared with anatase $\mathrm{TiO}_{2}$, brookite $\mathrm{TiO}_{2}$ has (i) a higher driving force with more favorable energy-level alignment with the perovskite layer, (ii) higher capacity for charge transfer, (iii) increased crystallinity, (iv) synthesis at relatively low temperature, (v) higher conductivity, (vi) higher electron mobility to facilitate photogenerated electron collection, and (vii) higher thermal stability [80-82]. The conduction band edge of brookite is slightly higher than those of anatase and rutile $\mathrm{TiO}_{2}$, which is expected to promote efficient electron transfer from the brookite to the anatase phase (Figure $5 b$ ). The close match of the conduction band edge of brookite with the band structure of perovskites might increase both the open-circuit voltage $\left(V_{\mathrm{oc}}\right)$ and efficiency of PSCs. The higher driving force with a more negative flat-band potential and more efficient charge separation and lower resistance of the brookite phase of $\mathrm{TiO}_{2}$ with perovskite can be compared with the case for the anatase phase [80]. Charge transport at the semiconductor/electrolyte interface can be influenced by the semiconducting properties of the $\mathrm{TiO}_{2}$ phase because the brookite phase shows higher conductivity and thermal stability than the anatase [81]. Miyasaka and co-workers fabricated compact $\mathrm{TiO}_{\mathrm{x}} / \mathrm{mp}$-brookite $\mathrm{TiO}_{2}$-based PSCs with a PCE of $21.6 \%$ and high $V_{\mathrm{oc}}$ because of the relative conduction-band level of the brookite layer to that of the perovskite [83]. PSCs with brookite $\mathrm{TiO}_{2}$ exhibited a higher $V_{\text {oc }}$ than those with other phases of $\mathrm{TiO}_{2}$. Thus, it is important to explore the performance of PSCs containing ETLs composed of single-phase anatase or brookite and those with anatase-brookite (AB) and brookite-anatase (BA) heterophase junctions to best manipulate the charge transport characteristics of each phase. Recently, we fabricated $\mathrm{TiO}_{2}$ heterophase junctions at low temperature $\left(<180^{\circ} \mathrm{C}\right)$ and tested their performance in PSCs. We used different $\mathrm{TiO}_{2}$ phases to manipulate the charge transfer in $\mathrm{TiO}_{2}$ semiconductor junctions in PSCs (Figure $5 \mathrm{~d}, \mathrm{f}$ ). We also found that PSC efficiency can be improved by changing the crystalline phase of the $\mathrm{TiO}_{2} \mathrm{CL}$. We showed that PSCs with FTO-AB as an ETL exhibited high efficiency up to $16.82 \%$ [66]. In addition, the results suggested that single-phase brookite $\mathrm{TiO}_{2}$ NPs without a $\mathrm{TiO}_{2} \mathrm{CL}$ can act as an effective ETL in PSCs. These PSCs exhibited a 
PCE of $14.92 \%$, which was comparable to the first work reported by Miyasaka and co-workers [83]. Because of their suitable internecking particles to particles structure, single-phase brookite $\mathrm{TiO}_{2} \mathrm{NPs}$ can block holes effectively. The large specific surface area of brookite $\mathrm{TiO}_{2} \mathrm{NPs}$ allows efficient electron injection and subsequent transport that can balance the electron and hole current densities, strongly influencing the performance of PSCs. The rod-like brookite $\mathrm{TiO}_{2}$ particles used in these PSCs ranged from $30-50 \mathrm{~nm}$ in diameter (Figure 5a). Such particles form a porous scaffold film rather than a CL. These particles cannot be considered as mp-materials because they do not contain pores. According to International Union of Pure and Applied Chemistry (IUPAC) nomenclature, mp-materials possess pores with diameters of 2-50 nm. The performance and stability of PSCs are strongly influenced by the nature of the underlying substrate. Recently, we reported that the incorporation of brookite $\mathrm{TiO}_{2}$ NPs as a bridge between the $\mathrm{TiO}_{2} \mathrm{CL}$ and perovskite layer resulted in PSCs with highly reproducible PCEs of up to $18.2 \%$ with stable performance of $18 \%$ under continuous one-sun illumination during maximum power point tracking, light soaking, and ambient atmosphere (Figure 5g-i) [67]. In contrast, the corresponding planar device with only a $\mathrm{TiO}_{2} \mathrm{CL}$ exhibited a PCE of $\sim 15 \%$. Highly stable and conductive brookite $\mathrm{TiO}_{2} \mathrm{NPs}$ have been used as a bridge between perovskite and $\mathrm{TiO}_{2} \mathrm{CLs}$ [81]. The NPs facilitated efficient interfacial charge transfer and promoted large grain growth, consequently enhancing device stability and performance. These results indicate that brookite $\mathrm{TiO}_{2} \mathrm{NPs}$ can be considered an alternative to anatase $\mathrm{TiO}_{2}$-based materials in efficient and stable PSCs.

(a)

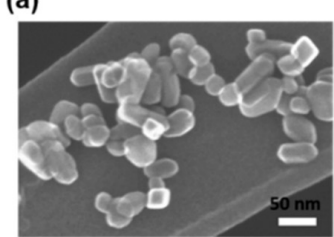

(d)

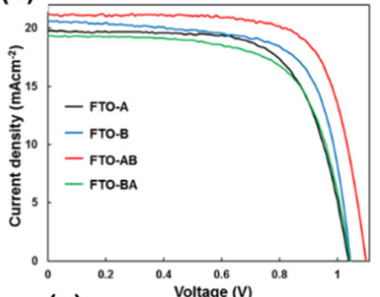

(g)

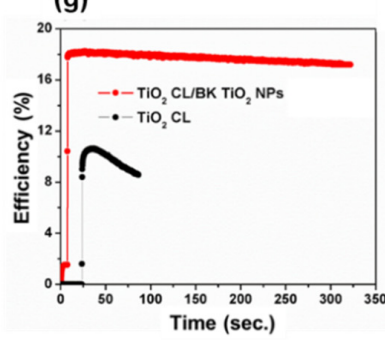

(b) First charge transport

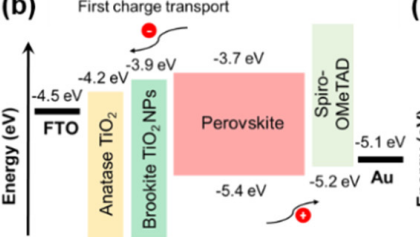

(e)

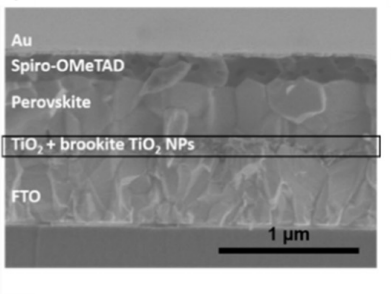

(h)

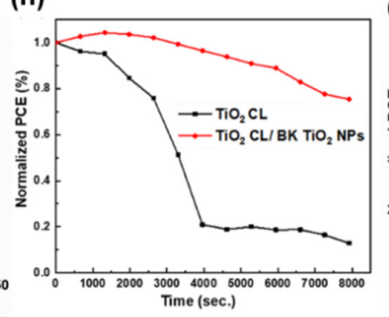

(c)

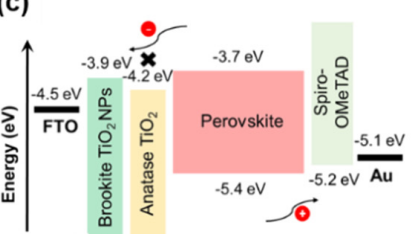

(f)

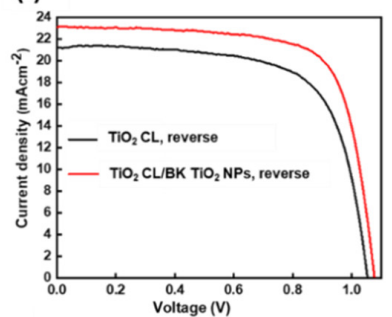

(i)

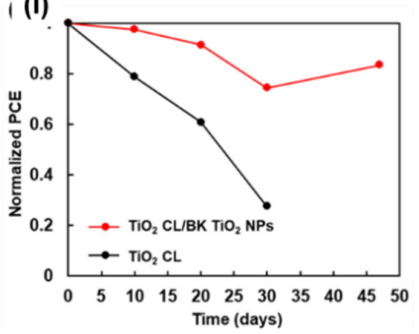

Figure 5. (a) Scanning transmission electron microscope (STEM) image of brookite (BK) $\mathrm{TiO}_{2} \mathrm{NPs}_{\text {. }}$ Schematic illustrations of the energy-level alignment in devices with (b) FTO-anatase-brookite (AB) and (c) FTO-brookite-anatase (BA) as electron transport layers (ETLs). (d) $J$ - $V$ curves of PSCs with FTO-anatase (A), FTO-brookite (B), FTO-AB, and FTO-BA as ETLs. (e) Cross-sectional SEM image of the PSC with an FTO-AB ETL. (f) Reverse $J$ - $V$ curves obtained for the PSCs on substrates with and without a brookite (BK) $\mathrm{TiO}_{2} \mathrm{NP}$ layer. (g) Efficiency at maximum power point under continuous one-sun illumination $\left(100 \mathrm{~mW} / \mathrm{cm}^{2}\right)$. Reproduced with permission [66]. Copyright 2019 American Chemical Society. (h) Normalized PCE vs. time (in seconds) of $\mathrm{TiO}_{2} \mathrm{CL} / \mathrm{BK} \mathrm{TiO}_{2} \mathrm{NP}$-based PSCs (non-encapsulated) after continuous exposure to one-sun illumination for $2.12 \mathrm{~h}$ in air with 60-70\% relative humidity. (i) Normalized PCE versus time (in days) of PSCs (non-encapsulated) stored in the dark under dry $\mathrm{N}_{2}$. The devices were measured under ambient conditions at $60-70 \%$ relative humidity. Reproduced with permission [67]. Copyright 2020, Royal Society of Chemistry. 


\subsubsection{Rutile $\mathrm{TiO}_{2} \mathrm{NPs}$}

The rutile $\mathrm{TiO}_{2}$ phase also shows potential in PSC applications because it is easy to synthesize. Several studies on the application of highly crystalline, oriented rutile $\mathrm{TiO}_{2}$ nanorods and nanowires in PSCs have been reported [84-87]. Park and co-workers reported efficient PSCs containing the rutile $\mathrm{TiO}_{2}$ phase [88]. However, rutile $\mathrm{TiO}_{2}$ has a more positive conduction band edge potential than that of anatase $\mathrm{TiO}_{2}$, resulting in an inferior $V_{\text {oc }}$ (Figure 6a). In addition, the inset shows more electrons injected to rutile $\mathrm{TiO}_{2}$ which can lower the Fermi energy level at equilibrium between $\mathrm{E}_{\mathrm{F}}\left(\mathrm{TiO}_{2}\right)$ and $\mathrm{E}_{\mathrm{F}}$ $\left(\mathrm{MAPbI}_{3}\right)$, resulting in the lower $V_{\text {oc }}$ (Figure 6d). Subsequently, Wu et al. synthesized rutile $\mathrm{TiO}_{2} \mathrm{NPs}$ by CBD [89]. The NPs were introduced onto FTO substrates for use as the ETL in PSCs, which exhibited a PCE of $15.4 \%$ and high reproducibility. $\mathrm{Li}$ et al. reported a facile fabrication of $\mathrm{TiO}_{2}$ nanorods by a solvothermal method [68]. The nanorods were incorporated in PSCs that exhibited a record PCE of $18.22 \%$. These results demonstrated that the dense and uniform rutile $\mathrm{TiO}_{2} \mathrm{NPs}$ strongly suppressed hysteresis, which improved the long-term stability of the resultant PSCs. Shao and co-workers grew rutile $\mathrm{TiO}_{2}$ thin films on FTO substrates by CBD [90]. PSCs containing these thin films exhibited PCEs of over $12 \%$. This approach is an effective way to produce $\mathrm{TiO}_{2}$-based PSCs at low temperature.

(a)
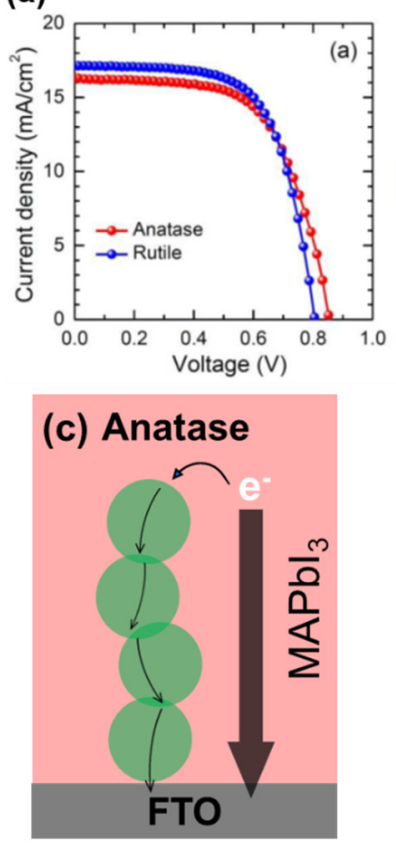

(b)

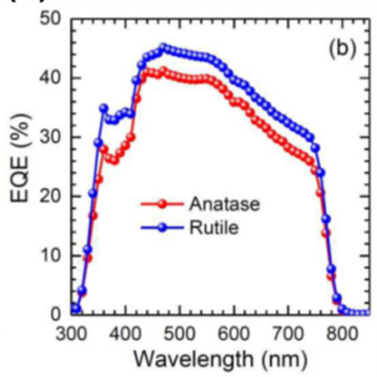

(d) Rutile

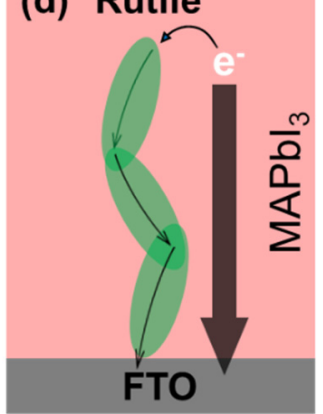

Figure 6. (a) $J-V$ curves and (b) incident photon-to-current efficiency (IPCE) spectra of devices containing anatase and rutile $\mathrm{TiO}_{2}$ thin films. Schematic of electronic behavior of devices with (c) anatase $\mathrm{TiO}_{2}$ and (d) rutile $\mathrm{TiO}_{2}$ films. Reproduced with permission [88]. Copyright 2014, Royal Society of Chemistry.

\subsection{Mesoporous $\mathrm{TiO}_{2}$}

Generally, fabrication of $\mathrm{mp}-\mathrm{TiO}_{2}$ films requires a complicated and time-consuming process that involves deposition of a $\mathrm{TiO}_{2} \mathrm{CL}$ followed by synthesis of $\mathrm{mp}-\mathrm{TiO}_{2}$. In addition to altering the crystalline phase (anatase) of the amorphous oxide film, $\mathrm{mp}-\mathrm{TiO}_{2}$ requires a high-temperature sintering process at more than $500{ }^{\circ} \mathrm{C}$ to improve electron transport properties and remove polymer template molecules. Such a high-temperature, time-consuming process limits the application of $\mathrm{mp}-\mathrm{TiO}_{2}$ in flexible PSCs fabricated by roll-to-roll processing. Graetzel et al. studied the influence of lithium-doped $\mathrm{mp}-\mathrm{TiO}_{2}$ on the performance of PSCs [91]. These PSCs showed superior electronic properties because the lithium-doped $\mathrm{mp}-\mathrm{TiO}_{2}$ lowered electronic trap states, which enabled faster electron transport. Subsequently, Miyasaka and co-workers reported efficient PSCs with a PCE of 21.1\% that showed 
negligible hysteresis by introducing alkali-metal dopants into mp- $\mathrm{TiO}_{2}$ (Figure 7) [44]. The doped $\mathrm{TiO}_{2}$ films strongly modulated electronic conductivity, which improved charge extraction and hindered charge recombination. In addition, the doped $\mathrm{TiO}_{2}$ thin film remarkably influenced the nucleation of the perovskite layer, which subsequently formed large grains that assembled into dense films with facetted crystallites. Huckaba et al. reported PSCs containing inkjet-printed $m p-\mathrm{TiO}_{2}$ films that exhibited with a PCE of $18.29 \%$ [92]. Overall, inkjet printing technology provides a scalable and reliable alternative to spin coating for large-scale applications. Sung et al. developed PSCs containing mp- $\mathrm{TiO}_{2}$ films composed of NPs with a size of $50 \mathrm{~nm}$, which displayed promising performance, including a PCE of $17.19 \%$ [93]. Extensive effort has been expended developing nanostructure-based ETL materials for use in PSC applications. Wang et al. revealed that the introduction of a nanocomposite of graphene/ $/ \mathrm{TiO}_{2} \mathrm{NPs}$ into mp-structured [94]. PSCs led to increased charge collection, which resulted in improved photovoltaic performance. Huang's group fabricated $\mathrm{mp}-\mathrm{TiO}_{2}$ nanopillars by room-temperature reactive magnetron sputtering [95]. The nanopillars were then used as the ETL in PSCs. The efficient $\mathrm{TiO}_{2} \mathrm{CL} / \mathrm{mp}-\mathrm{TiO}_{2}$ nanopillar scaffold achieved fast carrier extraction and thereby suppressed recombination loss. Several other efficient $\mathrm{mp}-\mathrm{TiO}_{2}$-based PSCs have also been reported to date $[96,97]$.
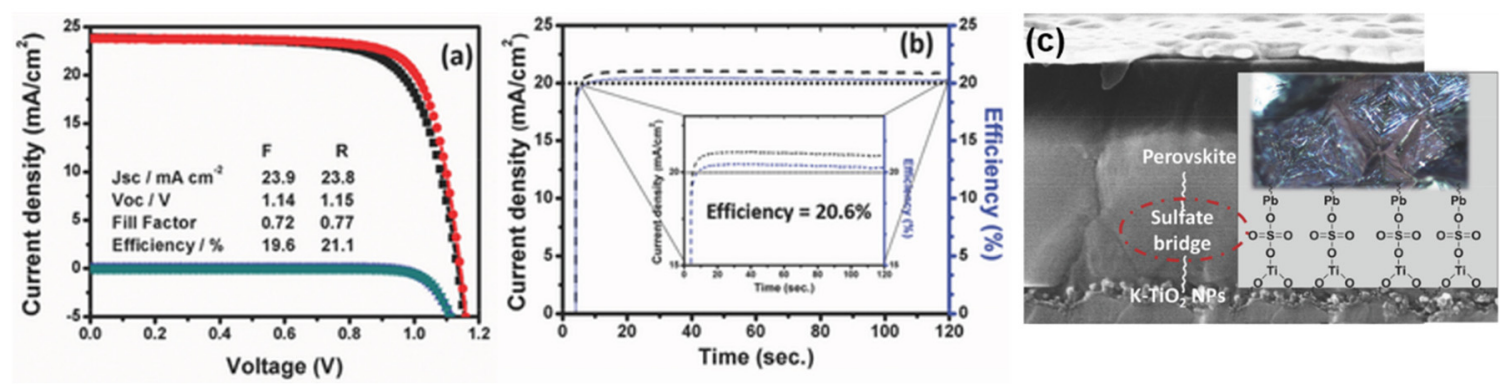

Figure 7. (a) $J-V$ characteristics of the best-performing PSC fabricated on K2 substrates, which showed a PCE of $21.1 \%$ and $V_{\text {OC }}$ of 1.15 V. (b) Steady-state PCE and $J_{S c}$ at maximum power point of the best-performing device. Inset is a magnified image of the efficiency (blue dotted line) and Jsc (black dotted line)). (c) Combined cross-sectional SEM image and schematic of a doped $\mathrm{TiO}_{2}$ mesoporous layer and the surface states bonding with the ETL and perovskite. Reproduced with permission [44]. Copyright 2018, Wiley-VCH Verlag GmbH \& Co. KGaA, Weinheim.

\subsection{Tin Dioxide}

$\mathrm{SnO}_{2}$ can be considered other potential ETLs widely used in PSCs owing to their favorable optoelectronics properties, such as wide optical bandgap, high electron mobility, high transparency in the visible and near infrared regions and suitable energy level match with perovskites, and simple fabrication of optically transparent dense films by several methods [98]. Miyasaka and colleagues have reported that PSCs with low-temperature processed $\mathrm{SnO}_{2}$ as an ETLs exhibited a PCE of $13 \%$ with high stable [99]. Hagfeldt et al. have reported a simple chemical bath post-treatment deposited $\mathrm{SnO}_{2}$ and used as ETL in PSCs that showed a PCE close to 21\% [33]. In addition, You and co-workers have been achieved an impressive planar PSCs with a record PCE of 20.9\% by incorporating of thin layer of $\mathrm{SnO}_{2}$ nanoparticle as ETLs [100]. In order to further improve the performance of $\mathrm{SnO}_{2}$ ETL based PSCs, the elemental doping and surface modification such as surface passivation and bilayer structure techniques have been employed. More importantly, elemental doping with various metal cations such as $\mathrm{Li}^{+}$, and $\mathrm{Sb}^{3+}$ in $\mathrm{SnO}_{2}$ ETLs exhibited efficient planar PSCs [101,102]. Furthermore, Fang and co-workers reported efficient PSCs with a PCE of $18 \%$ by using a 3-aminopropyltriethoxysilane self-assembled monolayer to modify the interface between the $\mathrm{SnO}_{2}$ and perovskite [103]. The defect passivation technique has been used in $\mathrm{SnO}_{2}$-based PSCs by using binary alkaline halides [104]. Yang et al. reported ethylene diaminetetraacetic acid (EDTA) modified $\mathrm{SnO}_{2}$, where EDTA facilitates more smooth interface between $\mathrm{SnO}_{2}$ /perovskite and better match with the conduction band of perovskite, resulting in efficient 
planar PSCs with a PCE of $21.52 \%$ [72]. Chen et al. reported PSCs with a PCE of $13.52 \%$ by inserting a simple spin-coating deposited $\mathrm{SnO}_{2}$ onto $\mathrm{TiO}_{2} \mathrm{CL}$ owing to cover cracks of the $\mathrm{TiO}_{2}$ hole-blocking layer [105]. Recently, Miyasaka and colleagues reported a stabilize high performance PSCs with a PCE of $22.1 \%$, where $\mathrm{TiO}_{2} \mathrm{CL}$ was modified by the $\mathrm{SnO}_{2}$ layer [70].

\subsection{Zinc Oxide}

$\mathrm{ZnO}$ is an outstanding inorganic semiconductor material because it is easy to synthesize, large surface area, and cost-effective fabrication. In addition, $\mathrm{ZnO}$ have been studied the most as CLs in PSCs because of their superior optoelectronic properties [106]. Recently, Kim and colleagues reported high-performance and stable PSCs by introducing SAM between ZnO ETL and perovskite in order to improve electron transfer from the perovskite layer to the ETL [32]. Cao et al. demonstrated an effective suppression of the corrosion of perovskite by incorporating the $\mathrm{SnO}_{2}$ layer between $\mathrm{ZnO}$ and perovskite layers [75]. The PSCs exhibited PCEs as high as $12.17 \%$ with minimal hysteresis.

\section{Other Metal Oxides}

Other $\mathrm{MO}_{\mathrm{x}}$ thin films such as $\mathrm{WO}_{3}[36,107,108], \mathrm{Zn}_{2} \mathrm{SnO}_{4}$ [109-112], $\mathrm{Nb}_{2} \mathrm{O}_{5}$ [37], $\mathrm{In}_{2} \mathrm{O}_{3}$ [113,114], $\mathrm{SrTiO}_{3}[115,116], \mathrm{BaTiO}_{3}[117,118], \mathrm{BaSnO}_{3}[119,120]$, and $\mathrm{ZrO}_{2}$ [35], have also been investigated for use as the potential CL in PSCs. The band gap of $\mathrm{WO}_{3}$ is smaller compared to $\mathrm{TiO}_{2}$, where it shows higher carrier mobility. Furthermore, Amassian and colleagues have demonstrated PSCs with a PCE of $11.24 \%$ by inserting a $\mathrm{TiCl}_{4}$ layer at the perovskite/ $\mathrm{WO}_{3}$ interface, implying significantly reduced charge recombination [121]. Modifying the known ETLs by elemental doping and morphology treatment, along with discovering a new $\mathrm{MO}_{\mathrm{x}}$ with superior properties, are required to further improve the performance and stability of PSCs.

\section{Summary and Outlook}

PSCs are attracting huge interest as next-generation thin-film photovoltaics with the hope of developing economically feasible power supplies to improve our environmental sustainability in the near future. However, several issues that currently hinder the commercialization of PSCs need to be considered, particularly their efficiency and stability. $\mathrm{TiO}_{2}$ thin films have been widely used as ETLs in PSCs because of their excellent electrical properties, high durability, suitable energy-level match with perovskites, and easy fabrication of optically transparent dense films by several techniques. Recently, numerous attempts to improve device performance and stability through interface modification of $\mathrm{TiO}_{2}$ CLs with different phases of $\mathrm{TiO}_{2} \mathrm{NPs}$, elemental doping, and solvent engineering have been explored. Ideal ETL modification needs to be simple, conducted at low temperature, cost-effective, and provide an ETL with high thermal and chemical stability, suitable band alignment with the perovskite, and excellent wettability with perovskite precursor solution to yield efficient and stable PSCs suitable for future commercialization. From this perspective, we reviewed the progress of bilayer ETLs, which have improved both the performance and stability of PSCs.

To further improve the operational stability of PSCs, simultaneous device engineering such as interface modification of $\mathrm{TiO}_{2} \mathrm{CL} /$ perovskite, tuning of the crystallinity, morphology, and compositional engineering (both cations/halogens) of the perovskite along with optimization of the organic/inorganic HTL should be considered to realize their full potential. In addition, techniques suitable for large-area fabrication at low cost are highly desired to enable the development of large-area PSC modules. Further optimization of $\mathrm{Pb}$-free perovskites may improve their sustainability to reach new heights in clean energy generation. Experiments should consider both the stability and efficiency of $\mathrm{Pb}$-based and $\mathrm{Pb}$-free PSCs to assist the solar energy revolution.

Author Contributions: Concept, M.S.; methodology, M.S.; visualization, M.A., J.-M.N. and T.T.; writing—original draft preparation, M.S.; review and editing, S.F., E.Y.M., L.W., M.N., M.A., M.K., K.T., J.-M.N. and T.T.; supervision, T.T. All authors have read and agreed to the published version of the manuscript. 
Funding: This research received no external funding.

Acknowledgments: This research work was partially supported by a 2019 Research Grant from the Mitani Foundation for Research and Development.

Conflicts of Interest: The authors declare no conflict of interest.

\section{References}

1. Beggs, C. Energy: Management, Supply and Conservation; Elsevier Ltd.: Oxford, UK, 2012.

2. Priya, S.; Inman, D.J. Energy Harvesting Technologies; Springer Science: New York, NY, USA, 2008.

3. Green, M.A. Thin-film solar cells: Review of materials, technologies and commercial status. J. Mater. Sci. Mater. Electron. 2007, 18, 15-19. [CrossRef]

4. Sze, S.M.; Ng, K.K. Physics of Semiconductor Devices; John Wiley \& Sons: Hoboken, NJ, USA, 2006.

5. Green, M.A. The path to $25 \%$ silicon solar cell efficiency: History of silicon cell evolution. Prog. Photovolt. Res. Appl. 2009, 17, 183-189. [CrossRef]

6. Park, N.-G. Perovskite solar cells: An emerging photovoltaic technology. Mater. Today 2015, 18, 65-72. [CrossRef]

7. Liu, Y.; Yang, Z.; Cui, D.; Ren, X.; Sun, J.; Liu, X.; Zhang, J.; Wei, Q.; Fan, H.; Yu, F.; et al. Two-inch-sized perovskite $\mathrm{CH}_{3} \mathrm{NH}_{3} \mathrm{PbX}_{3}(\mathrm{X}=\mathrm{Cl}, \mathrm{Br}, \mathrm{I})$ crystals: Growth and characterization. Adv. Mater. 2015, 27, 5176-5183. [CrossRef]

8. Luo, D.; Yang, W.; Wang, Z.; Sadhanala, A.; Hu, Q.; Su, R.; Shivanna, R.; Trindade, G.F.; Watts, J.F.; Xu, Z.; et al. Enhanced photovoltage for inverted planar heterojunction perovskite solar cells. Science 2018, 360, 1442-1446. [CrossRef]

9. Snaith, H.J. Perovskites: The emergence of a new era for low-cost, high-efficiency solar cells. J. Phys. Chem. Lett. 2013, 4, 3623-3630. [CrossRef]

10. Kojima, A.; Teshima, K.; Shirai, Y.; Miyasaka, T. Organometal halide perovskites as visible-light sensitizers for photovoltaic cells. J. Am. Chem. Soc. 2009, 131, 6050-6051. [CrossRef]

11. Best Research-Cell Efficiency Chart. Available online: https://www.nrel.gov/pv/assets/pdfs/pv-efficiencies04-14-2020.pdf (accessed on 14 April 2020).

12. Yang, J.; Yuan, Z.; Liu, X.; Braun, S.; Li, Y.; Tang, J.; Gao, F.; Duan, C.-G.; Fahlman, M.; Bao, Q. Oxygen- and water-induced energetics degradation in organometal halide perovskites. ACS Appl. Mater. Interfaces 2018, 10, 16225-16230. [CrossRef]

13. Meng, L.; You, J.; Yang, Y. Addressing the stability issue of perovskite solar cells for commercial applications. Nat. Commun. 2018, 9, 5265. [CrossRef]

14. Wang, P.; Zhang, X.; Zhou, Y.; Jiang, Q.; Ye, Q.; Chu, Z.; Li, X.; Yang, X.; Yin, Z.; You, J. Solvent-controlled growth of inorganic perovskite films in dry environment for efficient and stable solar cells. Nat. Commun. 2018, 9, 2225. [CrossRef]

15. Arora, N.; Dar, M.I.; Hinderhofer, A.; Pellet, N.; Schreiber, F.; Zakeeruddin, S.M.; Grätzel, M. Perovskite solar cells with CuSCN hole extraction layers yield stabilized efficiencies greater than $20 \%$. Science 2017, 358, 768-771. [CrossRef] [PubMed]

16. Jena, A.K.; Kulkarni, A.; Sanehira, Y.; Ikegami, M.; Miyasaka, T. Stabilization of $\alpha-\mathrm{CsPbI}_{3}$ in ambient room temperature conditions by incorporating Eu into $\mathrm{CsPbI}_{3}$. Chem. Mater. 2018, 30, 6668-6674. [CrossRef]

17. Pant, N.; Kulkarni, A.; Yanagida, M.; Shirai, Y.; Miyasaka, T.; Miyano, K. Investigating the growth of $\mathrm{CH}_{3} \mathrm{NH}_{3} \mathrm{PbI}_{3}$ Thin Films on RF-sputtered $\mathrm{NiO}_{\mathrm{x}}$ for inverted planar perovskite solar cells: Effect of $\mathrm{CH}_{3} \mathrm{NH}_{3}{ }^{+}$ halide additives versus $\mathrm{CH}_{3} \mathrm{NH}_{3}{ }^{+}$halide vapor annealing. Adv. Mater. Interfaces 2020, 7. [CrossRef]

18. Miyasaka, T.; Kulkarni, A.; Kim, G.M.; Öz, S.; Jena, A.K. Perovskite solar cells: Can we go organic-free, lead-free, and dopant-free? Adv. Energy Mater. 2020, 10, 1902500. [CrossRef]

19. Zong, Y.; Zhou, Y.; Zhang, Y.; Li, Z.; Zhang, L.; Ju, M.-G.; Chen, M.; Pang, S.; Zeng, X.C.; Padture, N.P. Continuous grain-boundary functionalization for high-efficiency perovskite solar cells with exceptional stability. Chem 2018, 4, 1404-1415. [CrossRef]

20. Saidaminov, M.I.; Kim, J.; Jain, A.; Quintero-Bermudez, R.; Tan, H.; Long, G.; Tan, F.; Johnston, A.; Zhao, Y.; Voznyy, O.; et al. Suppression of atomic vacancies via incorporation of isovalent small ions to increase the stability of halide perovskite solar cells in ambient air. Nat. Energy 2018, 3, 648-654. [CrossRef] 
21. Chaudhary, B.; Kulkarni, A.; Jena, A.K.; Ikegami, M.; Udagawa, Y.; Kunugita, H.; Ema, K.; Miyasaka, T. Poly(4-vinylpyridine)-based interfacial passivation to enhance voltage and moisture stability of lead halide perovskite solar cells. ChemSusChem 2017, 10, 2473-2479. [CrossRef]

22. Yang, J.-M.; Luo, Y.; Bao, Q.; Li, Y.-Q.; Tang, J.-X. Hall of fame article: Recent advances in energetics and stability of metal halide perovskites for optoelectronic applications. Adv. Mater. Interfaces 2019, 6, 1801351. [CrossRef]

23. Burschka, J.; Pellet, N.; Moon, S.-J.; Humphry-Baker, R.; Gao, P.; Nazeeruddin, M.K.; Grätzel, M. Sequential deposition as a route to high-performance perovskite-sensitized solar cells. Nature 2013, 499, 316-319. [CrossRef]

24. Jeon, N.J.; Noh, J.H.; Kim, Y.C.; Yang, W.S.; Ryu, S.; Seok, S.I. Solvent engineering for high-performance inorganic-organic hybrid perovskite solar cells. Nat. Mater. 2014, 13, 897-903. [CrossRef]

25. Yang, W.S.; Noh, J.H.; Jeon, N.J.; Kim, Y.C.; Ryu, S.; Seo, J.; Seok, S.I. High-performance photovoltaic perovskite layers fabricated through intramolecular exchange. Science 2015, 348, 1234-1237. [CrossRef] [PubMed]

26. Bi, D.; Yi, C.; Luo, J.; Décoppet, J.-D.; Zhang, F.; Zakeeruddin, S.M.; Li, X.; Hagfeldt, A.; Grätzel, M. Polymer-templated nucleation and crystal growth of perovskite films for solar cells with efficiency greater than 21\%. Nat. Energy 2016, 1, 16142. [CrossRef]

27. Yang, W.S.; Park, B.-W.; Jung, E.H.; Jeon, N.J.; Kim, Y.C.; Lee, D.U.; Shin, S.S.; Seo, J.; Kim, E.K.; Noh, J.H.; et al. Iodide management in formamidinium-lead-halide-based perovskite layers for efficient solar cells. Science 2017, 356, 1376-1379. [CrossRef] [PubMed]

28. Yu, X.; Marks, T.J.; Facchetti, A. Metal oxides for optoelectronic applications. Nat. Mater. 2016, 15, $383-396$. [CrossRef]

29. Juarez-Perez, E.J.; Wußler, M.; Fabregat-Santiago, F.; Lakus-Wollny, K.; Mankel, E.; Mayer, T.; Jaegermann, W.; Mora-Seró, I. Role of the selective contacts in the performance of lead halide perovskite solar cells. J. Phys. Chem. Lett. 2014, 5, 680-685. [CrossRef]

30. Moehl, T.; Im, J.H.; Lee, Y.H.; Domanski, K.; Giordano, F.; Zakeeruddin, S.M.; Dar, M.I.; Heiniger, L.-P.; Nazeeruddin, M.K.; Park, N.-G.; et al. Strong photocurrent amplification in perovskite solar cells with a porous $\mathrm{TiO}_{2}$ blocking layer under reverse bias. J. Phys. Chem. Lett. 2014, 5, 3931-3936. [CrossRef] [PubMed]

31. Ke, W.; Fang, G.; Wang, J.; Qin, P.; Tao, H.; Lei, H.; Liu, Q.; Dai, X.; Zhao, X. Perovskite solar cell with an efficient $\mathrm{TiO}_{2}$ compact film. ACS Appl. Mater. Interfaces 2014, 6, 15959-15965. [CrossRef]

32. Han, J.; Kwon, H.; Kim, E.; Kim, D.-W.; Son, H.J. Interfacial engineering of a ZnO electron transporting layer using self-assembled monolayers for high performance and stable perovskite solar cells. J. Mater. Chem. A 2020, 8, 2105-2113. [CrossRef]

33. Anaraki, E.H.; Kermanpur, A.; Steier, L.; Domanski, K.; Matsui, T.; Tress, W.R.; Saliba, M.; Abate, A.; Grätzel, M.; Hagfeldt, A.; et al. Highly efficient and stable planar perovskite solar cells by solution-processed tin oxide. Energy Environ. Sci. 2016, 9, 3128-3134. [CrossRef]

34. Azmi, R.; Hadmojo, W.T.; Sinaga, S.; Lee, C.-L.; Yoon, S.C.; Jung, I.H.; Jang, S.-Y. High-efficiency low-temperature $\mathrm{ZnO}$ based perovskite solar cells based on highly polar, nonwetting self-assembled molecular layers. Adv. Energy Mater. 2018, 8, 1701683. [CrossRef]

35. Mejía Escobar, M.A.; Pathak, S.; Liu, J.; Snaith, H.J.; Jaramillo, F. $\mathrm{ZrO}_{2} / \mathrm{TiO}_{2}$ Electron collection layer for efficient meso-superstructured hybrid perovskite solar cells. ACS Appl. Mater. Interfaces 2017, 9, 2342-2349. [CrossRef] [PubMed]

36. Gheno, A.; Pham, T.T.T.; Di Bin, C.; Bouclé, J.; Ratier, B.; Vedraine, S. Printable $\mathrm{WO}_{3}$ electron transporting layer for perovskite solar cells: Influence on device performance and stability. Sol. Energy Mater. Sol. Cells 2017, 161, 347-354. [CrossRef]

37. Ling, X.; Yuan, J.; Liu, D.; Wang, Y.; Zhang, Y.; Chen, S.; Wu, H.; Jin, F.; Wu, F.; Shi, G.; et al. Room-temperature processed $\mathrm{Nb}_{2} \mathrm{O}_{5}$ as the electron-transporting layer for efficient planar perovskite solar cells. ACS Appl. Mater. Interfaces 2017, 9, 23181-23188. [CrossRef] [PubMed]

38. Hashimoto, K.; Irie, H.; Fujishima, A. $\mathrm{TiO}_{2}$ Photocatalysis: A historical overview and future prospects. Jpn. J. Appl. Phys. 2005, 44, 8269-8285. [CrossRef]

39. O’Regan, B.; Grätzel, M.; Gr, M. A low-cost, high-efficiency solar cell based on dye-sensitized colloidal $\mathrm{TiO}_{2}$ films. Nature 1991, 353, 737-740. [CrossRef] 
40. Kim, H.-S.; Mora-Seró, I.; González-Pedro, V.; Fabregat-Santiago, F.; Juarez-Perez, E.J.; Park, N.-G.; Bisquert, J. Mechanism of carrier accumulation in perovskite thin-absorber solar cells. Nat. Commun. 2013, 4, 2242. [CrossRef]

41. Snaith, H.J.; Abate, A.; Ball, J.M.; Eperon, G.E.; Leijtens, T.; Noel, N.K.; Stranks, S.D.; Wang, J.T.-W.; Wojciechowski, K.; Zhang, W. Anomalous hysteresis in perovskite solar cells. J. Phys. Chem. Lett. 2014, 5, 1511-1515. [CrossRef]

42. Leijtens, T.; Eperon, G.E.; Pathak, S.; Abate, A.; Lee, M.M.; Snaith, H.J. Overcoming ultraviolet light instability of sensitized $\mathrm{TiO}_{2}$ with meso-superstructured organometal tri-halide perovskite solar cells. Nat. Commun. 2013, 4, 2885. [CrossRef]

43. Ito, S.; Tanaka, S.; Manabe, K.; Nishino, H. Effects of surface blocking layer of $\mathrm{Sb}_{2} \mathrm{~S}_{3}$ on nanocrystalline $\mathrm{TiO}_{2}$ for $\mathrm{CH}_{3} \mathrm{NH}_{3} \mathrm{PbI}_{3}$ perovskite solar cells. J. Phys. Chem. C 2014, 118, 16995-17000. [CrossRef]

44. Singh, T.; Öz, S.; Sasinska, A.; Frohnhoven, R.; Mathur, S.; Miyasaka, T. Sulfate-assisted interfacial engineering for high yield and efficiency of triple cation perovskite solar cells with alkali-doped $\mathrm{TiO}_{2}$ electron-transporting layers. Adv. Funct. Mater. 2018, 28, 1706287. [CrossRef]

45. Mohammadian-Sarcheshmeh, H.; Mazloum-Ardakani, M. Recent advancements in compact layer development for perovskite solar cells. Heliyon 2018, 4, e00912. [CrossRef] [PubMed]

46. Liu, M.; Johnston, M.B.; Snaith, H.J. Efficient planar heterojunction perovskite solar cells by vapour deposition. Nature 2013, 501, 395-398. [CrossRef] [PubMed]

47. Shahiduzzaman, M.; Yamamoto, K.; Furumoto, Y.; Kuwabara, T.; Takahashi, K.; Taima, T. Enhanced photovoltaic performance of perovskite solar cells via modification of surface characteristics using a fullerene interlayer. Chem. Lett. 2015, 44, 1735-1737. [CrossRef]

48. Shahiduzzaman, M.; Karakawa, M.; Yamamoto, K.; Kusumi, T.; Yonezawa, K.; Kuwabara, T.; Takahashi, K.; Taima, $\mathrm{T}$. Interface engineering of compact- $\mathrm{TiO}_{\mathrm{x}}$ in planar perovskite solar cells using low-temperature processable high-mobility fullerene derivative. Sol. Energy Mater. Sol. Cells 2018, 178, 1-7. [CrossRef]

49. Noh, J.H.; Im, S.H.; Heo, J.H.; Mandal, T.N.; Seok, S.I. Chemical management for colorful, efficient, and stable inorganic-organic hybrid nanostructured solar cells. Nano Lett. 2013, 13, 1764-1769. [CrossRef] [PubMed]

50. Wu, Y.; Yang, X.; Chen, H.; Zhang, K.; Qin, C.; Liu, J.; Peng, W.; Islam, A.; Bi, E.; Ye, F.; et al. Highly compact $\mathrm{TiO}_{2}$ layer for efficient hole-blocking in perovskite solar cells. Appl. Phys. Express 2014, 7, 052301. [CrossRef]

51. Chen, C.; Cheng, Y.; Dai, Q.; Song, H. Radio frequency magnetron sputtering deposition of $\mathrm{TiO}_{2}$ thin films and their perovskite solar cell applications. Sci. Rep. 2015, 5, 17684. [CrossRef]

52. Maruyama, T.; Arai, S. Titanium dioxide thin films prepared by chemical vapor deposition. Sol. Energy Mater. Sol. Cells 1992, 26, 323-329. [CrossRef]

53. Su, T.-S.; Hsieh, T.-Y.; Hong, C.-Y.; Wei, T.-C. Electrodeposited ultrathin $\mathrm{TiO}_{2}$ blocking layers for efficient perovskite solar cells. Sci. Rep. 2015, 5, 16098. [CrossRef]

54. Cojocaru, L.; Uchida, S.; Sanehira, Y.; Nakazaki, J.; Kubo, T.; Segawa, H. Surface treatment of the compact $\mathrm{TiO}_{2}$ layer for efficient planar heterojunction perovskite solar cells. Chem. Lett. 2015, 44, 674-676. [CrossRef]

55. Zhou, H.; Chen, Q.; Li, G.; Luo, S.; Song, T.-B.; Duan, H.-S.; Hong, Z.; You, J.; Liu, Y.; Yang, Y. Interface engineering of highly efficient perovskite solar cells. Science 2014, 345, 542-546. [CrossRef]

56. Deng, X.; Wilkes, G.C.; Chen, A.Z.; Prasad, N.S.; Gupta, M.C.; Choi, J.J. Room-temperature processing of $\mathrm{TiO}_{x}$ electron transporting layer for perovskite solar cells. J. Phys. Chem. Lett. 2017, 8, 3206-3210. [CrossRef] [PubMed]

57. Liu, Z.; Chen, Q.; Hong, Z.; Zhou, H.; Xu, X.; De Marco, N.; Sun, P.; Zhao, Z.; Cheng, Y.-B.; Yang, Y. Low-temperature $\mathrm{TiO}_{x}$ compact layer for planar heterojunction perovskite solar cells. ACS Appl. Mater. Interfaces 2016, 8, 11076-11083. [CrossRef] [PubMed]

58. Shahiduzzaman, M.; Yonezawa, K.; Yamamoto, K.; Ripolles, T.S.; Karakawa, M.; Kuwabara, T.; Takahashi, K.; Hayase, S.; Taima, T. Improved reproducibility and intercalation control of efficient planar inorganic perovskite solar cells by simple alternate vacuum deposition of $\mathrm{PbI}_{2}$ and CsI. ACS Omega 2017, 2, 4464-4469. [CrossRef] [PubMed]

59. Ren, X.; Xie, L.; Kim, W.B.; Lee, D.G.; Jung, H.S.; Liu, S. Chemical bath deposition of co-doped $\mathrm{TiO}_{2}$ electron transport layer for hysteresis-suppressed high-efficiency planar perovskite solar cells. Sol. RRL 2019, 3, 1900176. [CrossRef] 
60. Kuwabara, T.; Sugiyama, H.; Kuzuba, M.; Yamaguchi, T.; Takahashi, K. Inverted bulk-heterojunction organic solar cell using chemical bath deposited titanium oxide as electron collection layer. Org. Electron. 2010, 11, 1136-1140. [CrossRef]

61. Adhikari, T.; Shahiduzzaman, M.; Yamamoto, K.; Lebel, O.; Nunzi, J.-M. Interfacial modification of the electron collecting layer of low-temperature solution-processed organometallic halide photovoltaic cells using an amorphous perylenediimide. Sol. Energy Mater. Sol. Cells 2017, 160, 294-300. [CrossRef]

62. Shahiduzzaman, M.; Yamamoto, K.; Furumoto, Y.; Kuwabara, T.; Takahashi, K.; Taima, T. Ionic liquid-assisted growth of methylammonium lead iodide spherical nanoparticles by a simple spin-coating method and photovoltaic properties of perovskite solar cells. RSC Adv. 2015, 5, 77495-77500. [CrossRef]

63. Taima, T.; Shahiduzzaman, M.; Yamamoto, K.; Furumoto, Y.; Kuwabara, T.; Takahashi, K. Planar heterojunction type perovskite solar cells based on $\mathrm{TiO}_{\mathrm{x}}$ compact layer fabricated by chemical bath deposition. In Oxide-based Materials and Devices VII; International Society for Optics and Photonics: Bellingham, WA, USA, 2016; Volume 9749, p. 97491G. [CrossRef]

64. Shahiduzzaman, M.; Sakuma, T.; Kaneko, T.; Tomita, K.; Isomura, M.; Taima, T.; Umezu, S.; Iwamori, S. Oblique electrostatic inkjet-deposited $\mathrm{TiO}_{2}$ electron transport layers for efficient planar perovskite solar cells. Sci. Rep. 2019, 9, 1-8. [CrossRef]

65. Shahiduzzaman, M.; Ashikawa, H.; Kuniyoshi, M.; Visal, S.; Sakakibara, S.; Kaneko, T.; Katsumata, T.; Taima, T.; Iwamori, S.; Isomura, M.; et al. Compact $\mathrm{TiO}_{2} /$ Anatase $\mathrm{TiO}_{2}$ single-crystalline nanoparticle electron-transport bilayer for efficient planar perovskite solar cells. ACS Sustain. Chem. Eng. 2018, 6, 12070-12078. [CrossRef]

66. Shahiduzzaman, M.; Visal, S.; Kuniyoshi, M.; Kaneko, T.; Umezu, S.; Katsumata, T.; Iwamori, S.; Kakihana, M.; Taima, T.; Isomura, M.; et al. Low-temperature-processed brookite-based $\mathrm{TiO}_{2}$ heterophase junction enhances performance of planar perovskite solar cells. Nano Lett. 2018, 19, 598-604. [CrossRef] [PubMed]

67. Shahiduzzaman, M.; Kulkarni, A.; Visal, S.; Wang, L.; Nakano, M.; Karakawa, M.; Takahashi, K.; Umezu, S.; Masuda, A.; Iwamori, S.; et al. A single-phase brookite $\mathrm{TiO}_{2}$ nanoparticle bridge enhances the stability of perovskite solar cells. Sustain. Energy Fuels 2020, 4, 2009-2017. [CrossRef]

68. Li, X.; Dai, S.-M.; Zhu, P.; Deng, L.-L.; Xie, S.-Y.; Cui, Q.; Chen, H.; Wang, N.; Lin, H. Efficient perovskite solar cells depending on $\mathrm{TiO}_{2}$ Nanorod Arrays. ACS Appl. Mater. Interfaces 2016, 8, 21358-21365. [CrossRef]

69. Lee, Y.; Paek, S.; Cho, K.T.; Oveisi, E.; Gao, P.; Lee, S.; Park, J.-S.; Zhang, Y.; Humphry-Baker, R.; Asiri, A.M.; et al. Enhanced charge collection with passivation of the tin oxide layer in planar perovskite solar cells. J. Mater. Chem. A 2017, 5, 12729-12734. [CrossRef]

70. Kim, G.M.; Ishii, A.; Öz, S.; Miyasaka, T. MACl-assisted Ge doping of Pb-hybrid perovskite: A universal route to stabilize high performance perovskite solar cells. Adv. Energy Mater. 2020, 10, 1903299. [CrossRef]

71. Song, S.; Kang, G.; Pyeon, L.; Lim, C.; Lee, G.-Y.; Park, T.; Choi, J. Systematically optimized bilayered electron transport layer for highly efficient planar perovskite solar cells $(\eta=21.1 \%)$. ACS Energy Lett. 2017, 2 , 2667-2673. [CrossRef]

72. Yang, D.; Yang, R.; Wang, K.; Wu, C.; Zhu, X.; Feng, J.; Ren, X.; Fang, G.; Priya, S.; Liu, S. High efficiency planar-type perovskite solar cells with negligible hysteresis using EDTA-complexed $\mathrm{SnO}_{2}$. Nat. Commun. 2018, 9, 3239. [CrossRef]

73. Zuo, L.; Chen, Q.; De Marco, N.; Hsieh, Y.-T.; Chen, H.; Sun, P.; Chang, S.-Y.; Zhao, H.; Dong, S.; Yang, Y. Tailoring the Interfacial Chemical Interaction for High-Efficiency Perovskite Solar Cells. Nano Lett. 2016, 17, 269-275. [CrossRef]

74. Ke, W.; Zhao, D.; Xiao, C.; Wang, C.; Cimaroli, A.J.; Grice, C.; Yang, M.; Li, Z.; Jiang, C.-S.; Al-Jassim, M.; et al. Cooperative tin oxide fullerene electron selective layers for high-performance planar perovskite solar cells. J. Mater. Chem. A 2016, 4, 14276-14283. [CrossRef]

75. Wang, P.; Zhao, J.; Liu, J.; Wei, L.; Liu, Z.; Guan, L.; Cao, G. Stabilization of organometal halide perovskite films by $\mathrm{SnO}_{2}$ coating with inactive surface hydroxyl groups on $\mathrm{ZnO}$ nanorods. J. Power Sources 2017, 339, 51-60. [CrossRef]

76. Tomita, K.; Kobayashi, M.; Petrykin, V.; Yin, S.; Sato, T.; Yoshimura, M.; Kakihana, M. Hydrothermal synthesis of $\mathrm{TiO}_{2}$ nano-particles using novel water-soluble titanium complexes. J. Mater. Sci. 2007, 43, 2217-2221. [CrossRef]

77. Gan, X.; Wang, O.; Liu, K.; Du, X.; Guo, L.; Liu, H. 2D homologous organic-inorganic hybrids as light-absorbers for planer and nanorod-based perovskite solar cells. Sol. Energy Mater. Sol. Cells 2017, 162, 93-102. [CrossRef] 
78. He, X.; Wu, J.; Tu, Y.; Xie, Y.; Dong, J.; Jia, J.; Wei, Y.; Lan, Z. TiO 2 single crystalline nanorod compact layer for high-performance $\mathrm{CH}_{3} \mathrm{NH}_{3} \mathrm{PbI}_{3}$ perovskite solar cells with an efficiency exceeding $17 \%$. J. Power Sources 2016, 332, 366-371. [CrossRef]

79. Wei, D.; Ji, J.; Song, D.; Li, M.; Cui, P.; Li, Y.; Mbengue, J.M.; Zhou, W.; Ning, Z.; Park, N.-G. A TiO 2 embedded structure for perovskite solar cells with anomalous grain growth and effective electron extraction. J. Mater. Chem. A 2017, 5, 1406-1414. [CrossRef]

80. Choi, M.; Lim, J.; Baek, M.; Choi, W.; Kim, W.; Yong, K. Investigating the unrevealed photocatalytic activity and stability of nanostructured brookite $\mathrm{TiO}_{2}$ film as an environmental photocatalyst. ACS Appl. Mater. Interfaces 2017, 9, 16252-16260. [CrossRef]

81. Zhao, M.; Li, L.; Lin, H.; Yang, L.; Li, G. A facile strategy to fabricate large-scale uniform brookite $\mathrm{TiO}_{2}$ nanospindles with high thermal stability and superior electrical properties. Chem. Commun. 2013, 49, 7046. [CrossRef]

82. Mo, S.-D.; Ching, W.Y. Electronic and optical properties of three phases of titanium dioxide: Rutile, anatase, and brookite. Phys. Rev. B 1995, 51, 13023-13032. [CrossRef]

83. Kogo, A.; Sanehira, Y.; Numata, Y.; Ikegami, M.; Miyasaka, T. Amorphous metal oxide blocking layers for highly efficient low-temperature brookite $\mathrm{TiO}_{2}$-based perovskite solar cells. ACS Appl. Mater. Interfaces 2018, 10, 2224-2229. [CrossRef]

84. Qiu, J.; Qiu, Y.; Yan, K.; Zhong, M.; Mu, C.; Yan, H.; Yang, S. All-solid-state hybrid solar cells based on a new organometal halide perovskite sensitizer and one-dimensional $\mathrm{TiO}_{2}$ nanowire arrays. Nanoscale 2013, 5, 3245-3248. [CrossRef]

85. Yang, M.; Guo, R.; Kadel, K.; Liu, Y.; O’Shea, K.; Bone, R.; Wang, X.; He, J.; Li, W. Improved charge transport of $\mathrm{Nb}$-doped $\mathrm{TiO}_{2}$ nanorods in methylammonium lead iodide bromide perovskite solar cells. J. Mater. Chem. A 2014, 2, 19616-19622. [CrossRef]

86. Zhang, X.; Bao, Z.; Tao, X.; Sun, H.; Chen, W.; Zhou, X. Sn-doped $\mathrm{TiO}_{2}$ nanorod arrays and application in perovskite solar cells. RSC Adv. 2014, 4, 64001-64005. [CrossRef]

87. Kim, H.-S.; Lee, J.-W.; Yantara, N.; Boix, P.P.; Kulkarni, S.A.; Mhaisalkar, S.; Grätzel, M.; Park, N.-G. High Efficiency Solid-State Sensitized Solar Cell-Based on Submicrometer Rutile $\mathrm{TiO}_{2}$ nanorod and $\mathrm{CH}_{3} \mathrm{NH}_{3} \mathrm{PbI}_{3}$ Perovskite Sensitizer. Nano Lett. 2013, 13, 2412-2417. [CrossRef] [PubMed]

88. Lee, J.-W.; Lee, T.-Y.; Yoo, P.J.; Grätzel, M.; Mhaisalkar, S.; Park, N.-G. Rutile TiO2-based perovskite solar cells. J. Mater. Chem. A 2014, 2, 9251. [CrossRef]

89. Wu, S.; Cheng, C.; Jin, J.; Wang, J.; Peng, T. Low-temperature processed nanostructured rutile $\mathrm{TiO}_{2}$ array films for perovskite solar cells with high efficiency and stability. Sol. RRL 2017, 2, 1700164. [CrossRef]

90. Liang, C.; Wu, Z.; Li, P.; Fan, J.; Zhang, Y.; Shao, G. Chemical bath deposited rutile $\mathrm{TiO}_{2}$ compact layer toward efficient planar heterojunction perovskite solar cells. Appl. Surf. Sci. 2017, 391, 337-344. [CrossRef]

91. Giordano, F.; Abate, A.; Correa-Baena, J.-P.; Saliba, M.; Matsui, T.; Im, S.H.; Zakeeruddin, S.M.; Nazeeruddin, M.K.; Hagfeldt, A.; Graetzel, M. Enhanced electronic properties in mesoporous $\mathrm{TiO}_{2}$ via lithium doping for high-efficiency perovskite solar cells. Nat. Commun. 2016, 7, 10379. [CrossRef]

92. Huckaba, A.J.; Lee, Y.; Xia, R.; Paek, S.; Bassetto, V.C.; Oveisi, E.; Lesch, A.; Kinge, S.; Dyson, P.J.; Girault, H.; et al. Inkjet-printed mesoporous $\mathrm{TiO}_{2}$ and perovskite layers for high efficiency perovskite solar cells. Energy Technol. 2019, 7, 186. [CrossRef]

93. Sung, S.D.; Ojha, D.P.; You, J.S.; Lee, J.; Kim, J.; Lee, W.I. $50 \mathrm{~nm}$ sized spherical $\mathrm{TiO}_{2}$ nanocrystals for highly efficient mesoscopic perovskite solar cells. Nanoscale 2015, 7, 8898-8906. [CrossRef]

94. Wang, J.T.-W.; Ball, J.M.; Barea, E.; Abate, A.; Alexander-Webber, J.; Huang, J.; Saliba, M.; Mora-Seró, I.; Bisquert, J.; Snaith, H.J.; et al. Low-temperature processed electron collection layers of graphene/TiO 2 nanocomposites in thin film perovskite solar cells. Nano Lett. 2013, 14, 724-730. [CrossRef]

95. Huang, A.; Lei, L.; Zhu, J.; Yu, Y.; Liu, Y.; Yang, S.; Bao, S.; Jin, P. Controllable deposition of $\mathrm{TiO}_{2}$ nanopillars at room temperature for high performance perovskite solar cells with suppressed hysteresis. Sol. Energy Mater. Sol. Cells 2017, 168, 172-182. [CrossRef]

96. Shin, S.S.; Lee, S.J.; Seok, S.I. Metal oxide charge transport layers for efficient and stable perovskite solar cells. Adv. Funct. Mater. 2019, 29, 1900455. [CrossRef]

97. Singh, T.; Miyasaka, T.; Singh, J. ChemInform abstract: Role of metal oxide electron-transport layer modification on the stability of high performing perovskite solar cells. ChemSusChem 2016, 47, 2559-2566. [CrossRef] [PubMed] 
98. Xiong, L.; Guo, Y.; Wen, J.; Liu, H.; Yang, G.; Qin, P.; Fang, G. Review on the application of $\mathrm{SnO}_{2}$ in perovskite solar cells. Adv. Funct. Mater. 2018, 28, 1802757. [CrossRef]

99. Song, J.; Zheng, E.; Bian, J.; Wang, X.-F.; Tian, W.; Sanehira, Y.; Miyasaka, T. Low-temperature $\mathrm{SnO}_{2}$-based electron selective contact for efficient and stable perovskite solar cells. J. Mater. Chem. A 2015, 3, 10837-10844. [CrossRef]

100. Jiang, Q.; Chu, Z.; Wang, P.; Yang, X.; Liu, H.; Wang, Y.; Yin, Z.; Wu, J.; Zhang, Y.; You, J. Planar-structure perovskite solar cells with efficiency beyond 21\%. Adv. Mater. 2017, 29, 1703852. [CrossRef]

101. Bai, Y.; Fang, Y.; Deng, Y.; Wang, Q.; Zhao, J.; Zheng, X.; Zhang, Y.; Huang, J. Low-temperature solution-processed $\mathrm{Sb}: \mathrm{SnO}_{2}$ nanocrystals for efficient planar perovskite solar cells. ChemSusChem 2016, 9 , 2686-2691. [CrossRef]

102. Park, M.; Kim, J.-Y.; Son, H.J.; Lee, C.-H.; Jang, S.S.; Ko, M.J. Low-temperature solution-processed Li-doped $\mathrm{SnO}_{2}$ as an effective electron transporting layer for high-performance flexible and wearable perovskite solar cells. Nano Energy 2016, 26, 208-215. [CrossRef]

103. Yang, G.; Wang, C.; Lei, H.; Zheng, X.; Qin, P.; Xiong, L.; Zhao, X.; Yan, Y.; Fang, G. Interface engineering in planar perovskite solar cells: Energy level alignment, perovskite morphology control and high performance achievement. J. Mater. Chem. A 2017, 5, 1658-1666. [CrossRef]

104. Wang, P.; Wang, J.; Zhang, X.; Wang, H.; Cui, X.; Yuan, S.; Lu, H.; Tu, L.; Zhan, Y.; Zheng, L. Boosting the performance of perovskite solar cells through a novel active passivation method. J. Mater. Chem. A 2018, 6, 15853-15858. [CrossRef]

105. Ren, H.; Zou, X.; Cheng, J.; Ling, T.; Bai, X.; Chen, D. Facile solution spin-coating $\mathrm{SnO}_{2}$ thin film covering cracks of $\mathrm{TiO}_{2}$ hole blocking layer for perovskite solar cells. Coatings 2018, 8, 314. [CrossRef]

106. Zhang, D.; Zhang, X.; Bai, S.; Liu, C.; Li, Z.; Guo, W.; Gao, F. Surface chlorination of ZnO for perovskite solar cells with enhanced efficiency and stability. Sol. RRL 2019, 3, 1900154. [CrossRef]

107. Ali, F.; Pham, N.D.; Fan, L.; Tiong, V.; Dai, X.; Bell, J.M.; Wang, H.; Tesfamichael, T.; Ostrikov, K. Low hysteresis perovskite solar cells using an electron-beam evaporated $\mathrm{WO}_{3-x}$ thin film as the electron transport layer. ACS Appl. Energy Mater. 2019, 2, 5456-5464. [CrossRef]

108. You, Y.; Tian, W.; Min, L.; Cao, F.; Deng, K.; Li, L. $\mathrm{TiO}_{2} / \mathrm{WO}_{3}$ bilayer as electron transport layer for efficient planar perovskite solar cell with efficiency exceeding 20\%. Adv. Mater. Interfaces 2020, 7, 1901406. [CrossRef]

109. Dou, J.; Zhang, Y.; Wang, Q.; Abate, A.; Li, Y.; Wei, M. Highly efficient $\mathrm{Zn}_{2} \mathrm{SnO}_{4}$ perovskite solar cells through band alignment engineering. Chem. Commun. 2019, 55, 14673-14676. [CrossRef] [PubMed]

110. Dou, J.; Shen, D.; Li, Y.; Abate, A.; Wei, M. Highly efficient perovskite solar cells based on a $\mathrm{Zn}_{2} \mathrm{SnO}_{4}$ compact layer. ACS Appl. Mater. Interfaces 2019, 11, 36553-36559. [CrossRef] [PubMed]

111. Zheng, M.; Xu, W.; Yuan, H.; Wu, J. Mesostructured perovskite solar cells based on $\mathrm{Zn}_{2} \mathrm{SnO}_{4}$ single crystal mesoporous layer with efficiency of 18.32\%. J. Alloys Compd. 2020, 823, 153730. [CrossRef]

112. Shin, S.S.; Yang, W.S.; Noh, J.H.; Suk, J.H.; Jeon, N.J.; Park, J.H.; Kim, J.S.; Seong, W.M.; Seok, S.I. High-performance flexible perovskite solar cells exploiting $\mathrm{Zn}_{2} \mathrm{SnO}_{4}$ prepared in solution below $100{ }^{\circ} \mathrm{C}$. Nat. Commun. 2015, 6, 7410. [CrossRef]

113. Chen, P.; Yin, X.; Que, M.; Yang, Y.; Liu, X.; Que, W. Bilayer photoanode approach for efficient $\operatorname{In}_{2} \mathrm{O}_{3}$ based planar heterojunction perovskite solar cells. J. Alloy. Compd. 2018, 735, 938-944. [CrossRef]

114. Yoon, S.; Kim, S.J.; Kim, H.S.; Park, J.-S.; Han, I.K.; Jung, J.W.; Park, M. Solution-processed indium oxide electron transporting layers for high-performance and photo-stable perovskite and organic solar cells. Nanoscale 2017, 9, 16305-16312. [CrossRef]

115. Okamoto, Y.; Fukui, R.; Fukazawa, M.; Suzuki, Y. $\mathrm{SrTiO}_{3} / \mathrm{TiO}_{2} \mathrm{composite}$ electron transport layer for perovskite solar cells. Mater. Lett. 2017, 187, 111-113. [CrossRef]

116. Mahmoudi, T.; Wang, Y.; Hahn, Y.-B. $\mathrm{SrTiO}_{3} / \mathrm{Al}_{2} \mathrm{O}_{3}$-graphene electron transport layer for highly stable and efficient composites-based perovskite solar cells with 20.6\% efficiency. Adv. Energy Mater. 2020, 10, 1903369. [CrossRef]

117. Qin, J.; Zhang, Z.; Shi, W.; Liu, Y.; Gao, H.; Mao, Y. Enhanced performance of perovskite solar cells by using ultrathin $\mathrm{BaTiO}_{3}$ interface modification. ACS Appl. Mater. Interfaces 2018, 10, 36067-36074. [CrossRef] [PubMed]

118. Okamoto, Y.; Suzuki, Y. Mesoporous $\mathrm{BaTiO}_{3} / \mathrm{TiO}_{2}$ double layer for electron transport in perovskite solar cells. J. Phys. Chem. C 2016, 120, 13995-14000. [CrossRef] 
119. Shin, S.S.; Yeom, E.J.; Yang, W.S.; Hur, S.; Kim, M.G.; Im, J.; Seo, J.; Noh, J.H.; Seok, S.I. Colloidally prepared La-doped $\mathrm{BaSnO}_{3}$ electrodes for efficient, photostable perovskite solar cells. Science 2017, 356, $167-171$. [CrossRef] [PubMed]

120. Zhu, L.; Ye, J.; Zhang, X.; Zheng, H.; Liu, G.; Pan, X.; Dai, S. Performance enhancement of perovskite solar cells using a La-doped $\mathrm{BaSnO}_{3}$ electron transport layer. J. Mater. Chem. A 2017, 5, 3675-3682. [CrossRef]

121. Mahmood, K.; Swain, B.S.; Kirmani, A.R.; Amassian, A. Highly efficient perovskite solar cells based on a nanostructured $\mathrm{WO}_{3}-\mathrm{TiO}_{2}$ core-shell electron transporting material. J. Mater. Chem. A 2015, 3, 9051-9057. [CrossRef]

(C) 2020 by the authors. Licensee MDPI, Basel, Switzerland. This article is an open access article distributed under the terms and conditions of the Creative Commons Attribution (CC BY) license (http://creativecommons.org/licenses/by/4.0/). 